\title{
Recent Research Trend of Zinc-ion Secondary Battery Materials for Next Generation Batterie
}

\author{
Jeonggeun Jo and Jaekook Kim ${ }^{\dagger}$
}

Chonnam National University

\section{차세대 이차전지용 아연 이온 이차전지 소재 연구 개발 동향}

\author{
조정근, 김재국 ${ }^{\dagger}$ \\ 전남대학교 신소재공학과
}

(Received November 21, 2018; Accepted December 17, 2018)

\begin{abstract}
s
Energy storage/conversion has become crucial not only to meet the present energy demand but also more importantly to sustain the modern society. Particularly, electrical energy storage is critical not only to support electronic, vehicular and load-levelling applications but also to efficiently commercialize renewable energy resources such as solar and wind. While Li-ion batteries are being intensely researched for electric vehicle applications, there is a pressing need to seek for new battery chemistries aimed at stationary storage systems. In this aspect, Zn-ion batteries offer a viable option to be utilized for high energy and power density applications since every intercalated $\mathrm{Zn}$-ion yields a concurrent charge transfer of two electrons and thereby high theoretical capacities can be realized. Furthermore, the simplicity of fabrication under open-air conditions combined with the abundant and less toxic zinc element makes aqueous $\mathrm{Zn}$-ion batteries one of the most economical, safe and green energy storage technologies with prospective use for stationary grid storage applications. Also, $\mathrm{Zn}$-ion batteries are very safe for next-generation technologies based on flexible, roll-up, wearable implantable devices the portable electronics market. Following this advantages, a wide range of approaches and materials, namely, cathodes, anodes and electrolytes have been investigated for $\mathrm{Zn}$-ion batteries applications to date. Herein, we review the progresses and major advancements related to aqueous. $\mathrm{Zn}$-ion batteries, facilitating energy storage/conversion via $\mathrm{Zn}^{2+}$ (de)intercalation mechanism.
\end{abstract}

Keywords: Energy storage system, Next generation batteries, Polyvalent ions, Zn-ion batteries, 
(a)

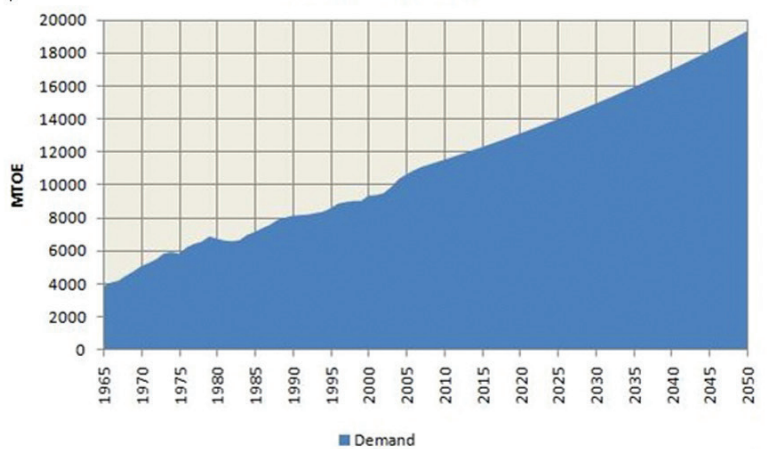

(b)

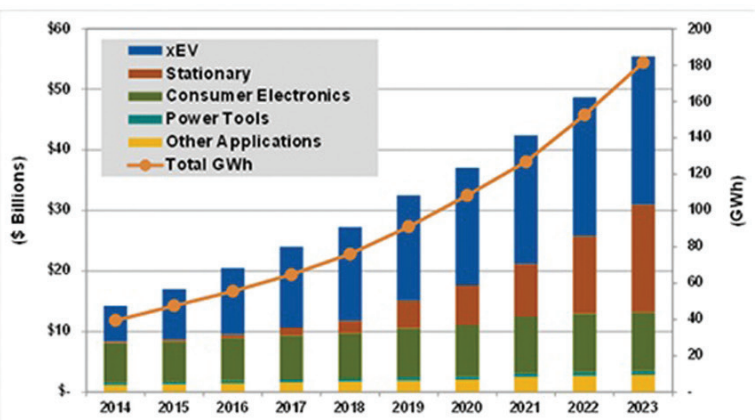

Fig. 1. (a) The expected energy demand road map until 2050, as presented by BP Statistical review of world energy 2007 (MOTE stands for Millions of Tons of Oil Equivalent), (b) Advanced battery revenue and energy capacity classified by applications.
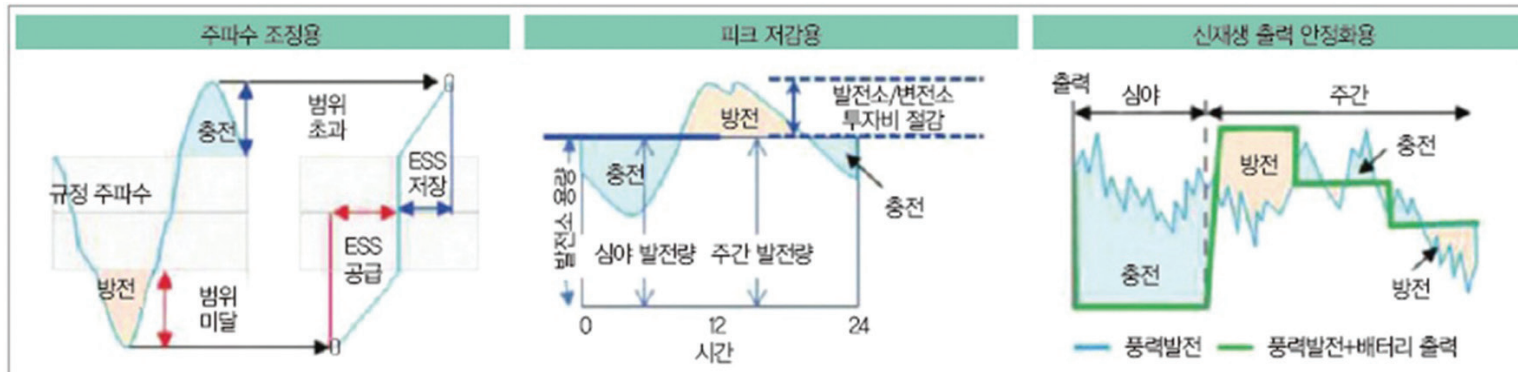

Fig. 2. Characteristics of Energy Storage System(ESS) by application.

Table 1. Domestic and foreign technology status and characteristics of major energy storage devices for Energy Storage System (ESS)

\begin{tabular}{|c|c|c|c|c|c|c|}
\hline 경쟁 기술 & 리튬 이온 전지 & 나트륨 · 황전지 & 레독스 흐름전지 & 슈퍼커패시터전지 & 플라이휠 & 압축공기저장 \\
\hline 최고 기술 보유 & $\begin{array}{c}\text { 미쓰비시 중공업(일) } \\
\text { GS YUASA(일) }\end{array}$ & NGK(일) & Prudent Energy(중) & $\begin{array}{c}\text { Panasonic(일) } \\
\text { Maxwell(미) }\end{array}$ & BOEING(미) & PG\&E(미) \\
\hline 국내 주요 기업 & $\begin{array}{l}\text { 삼성 } \mathrm{SDI} \\
\mathrm{LG} \text { 화학 }\end{array}$ & 포스코 & $\begin{array}{c}\text { OCI } \\
\text { 호남석유화학 }\end{array}$ & $\begin{array}{c}\text { 네스캡 } \\
\mathrm{LS} \text { 엠트론 }\end{array}$ & 전력연구원 & 환화 테크원 \\
\hline R\&D 수준 & 응용제품 개발 & 초기개발 & 초기개발 & 응용제품개발 & 제품개발 & 초기개발 \\
\hline 장점 & \begin{tabular}{|c} 
높은 에너지밀도 \\
효율 \\
소형화 적합
\end{tabular} & $\begin{array}{c}\text { 쉬운 에너지 밀도 } \\
\text { 저장용량 향상 가능 } \\
\text { 낮은 초기 비용 }\end{array}$ & $\begin{array}{l}\text { 낮은 시스템 비용 } \\
\text { 쉬운 대용량화 } \\
\text { 장기사용(20년) }\end{array}$ & $\begin{array}{c}\text { 빠른 충 } \cdot \text { 방전 속도 } \\
\text { 장기사용 } \\
\text { (> } 50 \text { 만 사이클 })\end{array}$ & $\begin{array}{l}\text { 높은 에너지 효율 } \\
\text { 장기사용( } 20 \text { 년) } \\
\text { 급속저장(분 단위) }\end{array}$ & $\begin{array}{c}\text { 대규모 에너지 저장 } \\
(>100 \mathrm{MW}) \\
\text { 낮은 발전 단가 }\end{array}$ \\
\hline 단점 & $\begin{array}{l}\text { 수명검증 미완료 } \\
\text { 낮은 저장용량 } \\
\text { (3kW 3MW) }\end{array}$ & \begin{tabular}{|c} 
낮은 출력 · 저장용량 \\
고온 시스템 필요
\end{tabular} & $\begin{array}{c}\text { 높은 초기 투자비용 } \\
\text { 낮은 에너지 밀도 } \\
\text { 효율 }\end{array}$ & $\begin{array}{l}\text { 낮은 에너지 밀도 } \\
\text { 높은 시스템 비용 }\end{array}$ & $\begin{array}{c}\text { 高 초기 제작 비용 } \\
\text { 낮은 에너지 밀도 } \\
\text { 동력효율 저하 } \\
\text { (장기간 사용) }\end{array}$ & $\begin{array}{c}\text { 높은 초기 구축비용 } \\
\text { 지리적 제약 }\end{array}$ \\
\hline 現 이슈 & $\begin{array}{l}\text { 전지가격 하락 } \\
\text { 적용범위 확대 } \\
\text { (중·대형 시장) }\end{array}$ & \begin{tabular}{|c|} 
전력설비 $\cdot$ 가정용 \\
대상 실증사업 진행
\end{tabular} & $\begin{array}{l}\text { 전력안정화 · 자동차 } \\
\text { 충전시설 적용 연구 }\end{array}$ & $\begin{array}{c}\text { 리튬이온전지 대체 } \\
\text { 예상 } \\
\text { 40Wh/kg 이상) }\end{array}$ & $\begin{array}{c}\text { 이동형(전기차 · } \\
\text { 건설기기) } \\
\text { 고정형(철도 · } \\
\text { 전력망) 중심연구 }\end{array}$ & $\begin{array}{l}\text { 상용화 어려움 } \\
\text { (지리적 제약) }\end{array}$ \\
\hline
\end{tabular}




\section{1. 서론}

세계의 전기 수요량은 1990 년부터 현재까지 전체 에너 지 소비의 2 배가 넘게 증가했으며, 향후 20 년 동안 $2 / 3$ 이상 증가 할 것으로 전망된다. (Fig. 1.) 따라서 에너지 저장/전환 기술은 현재 사회에서 지속 가능한 삶을 향한 중요한 연구 주제로 각광받고 있다.

현재는 전기를 생산하기 위한 시설로 화력발전소, 원자 력발전소 등을 이용하지만 화석연료의 고갈과 환경오염, 지구온난화 문제로 인해 풍력이나 태양광 같은 깨끗한 신 재생 에너지를 이용한 안정적인 에너지 생산을 추고하고 있다. 이러한 신재생 에너지 활용 확대를 위해서는 피크 시간대 에너지를 저장했다가 에너지가 필요한 시간 및 부 족한 시간에 사용할 수 있도록 에너지를 조절 및 분배하 는 대용량 전력저장 시스템(ESS; Energy Storage System)이 필요하다. ${ }^{1-3)}$ (Fig. 2.)

대용량 전력저장 시스템의 경쟁력을 좌우하는 가장 중 요한 요소는 에너지저장 매체로 활용되는 전지이며 현재 적용 가능한 기술로는 납축전지, 리튬 이온 이차전지 (LIB), 나트륨-황 전지 $(\mathrm{Na}-\mathrm{S})$, 레독스 플로우 전지 (RFB)가 경쟁을 벌이고 있다. (Table. 1) 대용량 전력저 장 시스템용 전지는 전기자동차용 전지에 비해 설치 공간 에 제약을 덜 받기 때문에 상대적으로 전지의 수명 및 안 정성, 그리고 가격적인 요인이 중요하다. 이를 위해 각 전 지의 특성을 결정하는 원천소재기술 개발에 대한 전 세계 적인 경쟁이 본격화 되고 있다. 이러한 전지 중 리튬 이온 이차전지는 높은 에너지 변환효율을 가지며, 유지 및 보 수가 간단하여 대용량 전력저장 시스템용 전지로 가장 선 호되고 있다. 특히, 리튬 이온 이차전지는 소형 전지시장 및 중대형 전지시장을 통제 할 수 있는 가장 유망한 기술 중 하나이며, 미래의 다양한 애플리케이션을 위한 소비량 은 꾸준히 증가할 것으로 예상된다. ${ }^{4,5)}$ 하지만 리튬 매장 량에 한계가 있어 늘어나는 수요를 충족시킬 수 없다는 분석이 나오고 있다. 따라서 차세대 이차전지의 개발이 미래의 에너지 시장에서 중요한 역할을 할 것이다.

이러한 시장 동향에 따라, 리튬에 비해 가격경쟁력이 뛰어난 나트륨 $(\mathrm{Na})$, 포타슘 $(\mathrm{K})$ 을 이용한 차세대 이온 배
터리가 대안으로 개발되고 있으나, 좁은 전압영역에서 가 역적으로 저장되는 전하의 양을 증가시키기 위해서는 하 나 이상의 전자를 수용할 수 있는 다가 양이온을 이용한 배터리를 개발해야 한다. 즉, 아연 $\left(\mathrm{Zn}^{2+}\right)$, 마그네슘 $\left(\mathrm{Mg}^{2+}\right)$, 칼슘 $\left(\mathrm{Ca}^{2+}\right)$ 등과 같이 하나의 전하수송체 이온이 삽 - 탈리 됨에 따라 2 개의 전자가 이동하여 저장되는 전 하의 양을 증가시키는 다가 양이온을 전하수송체로 사용 하는 배터리를 개발해야 한다. ${ }^{6-8)}$

다양한 다가 양이온 중 아연 2가 이온 $\left(\mathrm{Zn}^{2+}-74 \mathrm{pm}\right)$ 은 기존의 리튬 1 가 이온 $\left(\mathrm{Li}^{+}-69 \mathrm{pm}\right)$ 과 이온 반경이 비슷하 여 리튬 이온 이차전지 시스템에 활용하기 적합하다. ${ }^{9}$ 또 한 아연 금속의 가역적인 아연 이온 증착성과 높은 이론 용량 $\left(\sim 20 \mathrm{mAh} \mathrm{g}^{-1}\right)$, 낮은 가격으로 가격 경쟁력을 높일 수 있다는 장점이 있다. 마지막으로 수계 전해질을 활용 하는 아연 이온 이차전지의 제조 환경은 앞선 차세대 이 차전지와 달리 친환경적이며, 유기용매 전해질을 활용하 지 않아 저비용, 전도도가 우수하다는 장점이 있어 저가 형 친환경 이차전지를 얻을 수 있는 가능성을 보여주고 있다. (Fig. 3.)

대표적인 아연 이온 이차전지는 1950 년대에 소개되었 으며 음극으로 아연 금속, 양극으로 $\mathrm{MnO}_{2}$ 및 알칼리성 $\mathrm{KOH}$ 전해질로 구성된 $\mathrm{Zn} / / \mathrm{MnO}_{2}$ 전지였으며 현재까지 도 휴대용 저장장치에서 활용되고 있다. 그러나 충 - 방전 과정에서 음극 및 양극표면에 비가역적으로 형성되는 $\mathrm{Zn}(\mathrm{OH})_{2}, \mathrm{Mn}_{3} \mathrm{O}_{4}$ 로 인해 전도도 감소와 용량감소가 발생

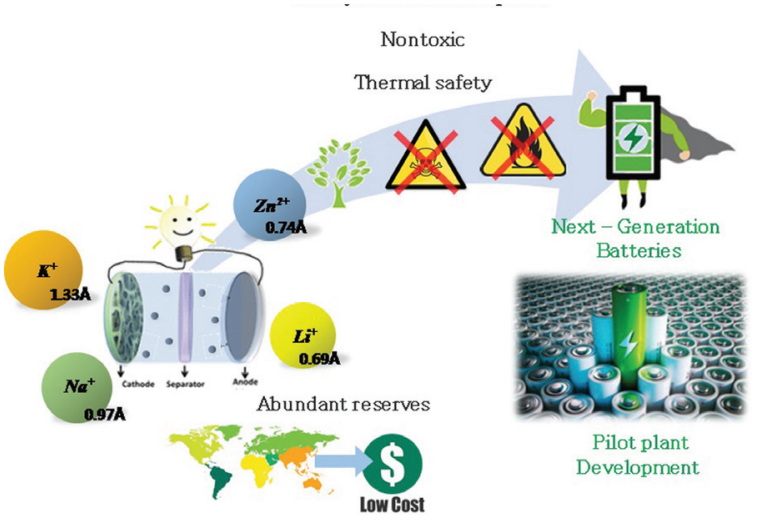

Fig. 3. Advantages of Zinc ion battery development for nextgeneration batteries. 
하며, 이에 따른 에너지 밀도감소로 인해 활용도가 현저 히 낮은 편이다. ${ }^{10-13)}$ 이를 보완하기 위해 2012년 Feiyu Kang 그룹의 연구에서는 전해질로 $\mathrm{ZnSO}_{4}$ 를 활용하여 약산성 조건으로 만들어 가역적인 아연 이온의 삽 · 탈리 를 확인하였다. ${ }^{8)}$ 하지만 아연 이온의 느린 삽 · 탈리 반응 속도와 아연 이온의 삽 · 탈리가 가능한 적절한 전극 구조 (tunnel, layered)를 선정하는데 제한이 있어 이에 대한 연구가 극히 드물었다.

위와 같이 아연 이온 이차전지는 차세대 에너지원으로 의 가능성이 높기 때문에 전극물질의 개발이나 구조개선, 시스템 개선 등 특성 향상에 대한 연구가 진행 되어야 한 다. 이와 관련하여 본 보고에서는 차세대 이차전지용 아 연 이온 이차전지의 소재 중 양극 및 음극 활물질 개발 현 황에 대해서 다루었으며 각 소재 별 특성 및 적용 예는 본 문에 상술하였다.

\section{2. 본문}

\section{1 양극소재}

\subsection{1망간계 양극 소재}

앞선 서론에서 언급한 것과 같이 초기 아연 이온 이차 전지에서 양극소재로 활용한 망간 산화물은 저비용 및 친 환경 특성과 전기화학적 거동을 촉진하는 독특한 구조적 특성으로 주목받았다. 동질이상체의 대표적 소재인 망간 산화물은 층상구조 $(\delta)$, 스피넬 구조 $(\lambda)$, 다양한 터널 $(\alpha$, $\beta, \gamma)$ 구조를 갖는다. ${ }^{14)}$ (Fig. 4.) 일반적으로 모든 구조의 $\mathrm{MnO}_{2}$ 는 2, 3차원적인 이온 이동 경로와 전자 구조의 특 성상 이온/전자 전도도가 높다. 또한 몰 질량이 작고 사 용가능 산화가가 높아 이론용량이 매우 높은 특성이 있 다. 하지만 구조에 따라 각 소재들은 다른 물리적, 전기 화학적 특성(용량, 작동전압, 고율 특성 등)을 발현하며 그 특성에 따라 리튬, 소듐, 아연 이온 전지, 리튬 공기전 지, 커패시터 등 다양한 에너지 저장분야에 적용되고 있 다. 그 중에서 $\alpha-\mathrm{MnO}_{2}$ 는 아연 이온 이차전지에 적용한 첫 양극소재로서 다양한 연구가 진행되었으며 이에 대한 전기화학 반응 메커니즘을 규명하기 위한 많은 연구가 진

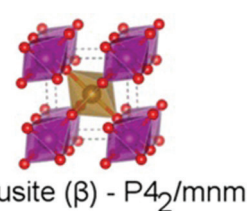

Pyrolusite $(\beta)-P 4_{2} / m n m$

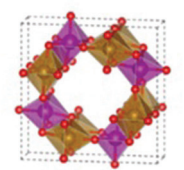

Hollandite ( $\alpha$ ) - 14/m



Layered (ס) - R $\overline{3} m$

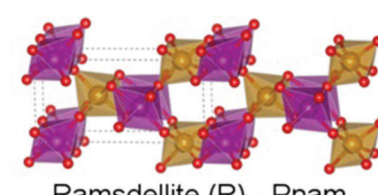

Ramsdellite (R) - Pnam

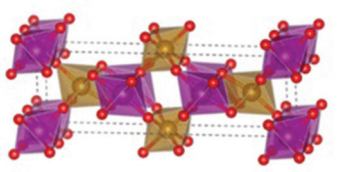

Intergrowth $(\mathrm{Y})$ - $\mathrm{C} 2 / \mathrm{m}$

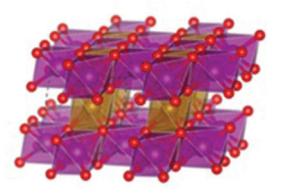

Spinel $(\lambda)-F d \overline{3} m$

Fig. 4. Schematic illustrations on crystal structure of isotropic structure of $\mathrm{MnO}_{2}$

행되었다. 그 결과들은 다음과 같으며, 전해질의 $\mathrm{pH}$ 조 건 및 입자의 형상에 따라 상이한 결과들이 확인되었으며 이에 대한 메커니즘도 상이하게 주장되고 있다.

먼저, 서론에서도 소개한 Feiyu Kang 그룹의 연구에 서는 $2 \times 2$ 터널 구조(크기 $\sim 4.6 \AA$ )를 갖는 $\alpha-\mathrm{MnO}_{2}$ 를 아연 이온 이차전지에 양극으로 적용, 약산성의 $\mathrm{ZnSO}_{4}$ 전해질 $\mathrm{pH} \sim 4.2)$ 조건에서 아연 이온이 가역적으로 삽 - 탈리 될 수 있음을 입증하였다. ${ }^{8)}$ 추가적으로 제 1 원 리 계산(First principle calculation)에 의해 아연 이온 을 수용하기 위한 $\alpha-\mathrm{MnO}_{2}$ 의 열역학적 안정성을 확인하 였다. ${ }^{15)}$ 이 전지는 첫 번째 방전 곡선의 $1.3 \mathrm{~V}$ 구간에서 단 일 평탄구간이 나타나며, 이후 사이클의 방전 곡선에서는 $1.3 \mathrm{~V}$ 및 $1.2 \mathrm{~V}$ 구간에서 두 개의 평탄구간이 나타나는 특 성을 발현하였다. 용량특성으로는 초기 개발되었던 알칼 리 $\mathrm{Zn} / / \mathrm{MnO}_{2}$ 전지 $\left(125 \mathrm{mAh} \mathrm{g}^{-1}\right)$ 보다 높은 $210 \mathrm{mAh} \mathrm{g}^{-1}$ 의 용량특성을 발현하며 $128 \mathrm{C}$ (약 56 초 만에 1 회의 충 . 방전이 완료되는 전류밀도) 조건에서도 $68 \mathrm{mAh} \mathrm{g}^{-1}$ 의 높 은 용량특성을 발현하였다. 충 - 방전 과정의 자세한 메커 니즘을 확인하기 위해 ex-situ X-ray Diffraction(XRD) 와 X-ray Photoelectron Spectroscopy(XPS)를 활용 하여 분석한 결과, $\alpha-\mathrm{MnO}_{2}$ 에 아연 이온이 삽 · 탈리 됨 에 따라 $\mathrm{Mn}^{4+} / \mathrm{Mn}^{3+}$ 의 산화 · 환원 반응이 발생하고 이로 
인해 스피넬 구조의 $\mathrm{ZnMn}_{2} \mathrm{O}_{4}$ 와 터널 구조의 $\alpha-\mathrm{MnO}_{2}$ 가 충 - 방전 과정에서 가역적으로 형성됨을 확인하였다.

Jaekook Kim 그룹은 나노 수지상 입자를 갖는 $\alpha-\mathrm{MnO}_{2}$ 를 양극으로 적용, $1 \mathrm{M} \mathrm{ZnSO}$ 전해질을 사용하 는 $\mathrm{Zn} / / \alpha-\mathrm{MnO}_{2}$ 전지를 활용하여 아연 이온이 가역적으 로 삽. 탈리 될 수 있음을 입증하였다. ${ }^{16)}$ 이에 대한 전기 화학 반응 메커니즘을 분석하기 위하여 ex-situ synchrotron X-ray Diffraction(XRD)와 X-ray Absorption Spectroscopy(XAS) 분석을 시행하였으며, 이를 통해 앞선 메커니즘 현상을 뒷받침 하였다. 충 - 방 전 과정에서 발생하는 아연 이온의 삽. 탈리에 의한 $\mathrm{Mn}^{4+} / \mathrm{Mn}^{3+}$ 의 산화 - 환원 반응이 발생함을 확인하였으 며, 이로 인해 단위 셀 부피의 팽창/수축이 유도됨을 확 인하였다. 이는 호흡의 메커니즘인 들숨/날숨과 유사하 며 충 - 방전 과정에서 $\mathrm{MnO}_{2}$ 구조에 아연 이온이 삽 · 탈 리 됨에 따라 반복됨을 확인하였다. 이러한 요인은 $16 \mathrm{~mA}$ $\mathrm{g}^{-1}$ 의 전류밀도 조건에서 $353 \mathrm{mAh} \mathrm{g}^{-1}$ 의 높은 방전용량 을 나타내며, 50 회 충 · 방전 이후에도 $288 \mathrm{mAh} \mathrm{g}^{-1}$ 의 용 량을 발현하여 우수한 용량 유지특성을 발현하는데 기인 함을 확인하였다. 추가적으로 두 그룹의 연구결과 모두 음극으로 활용된 아연 금속의 표면에 비 가역적인 부산물
이 형성되지 않음을 확인하였다.

한편, 앞선 두 그룹의 연구결과와 다르게 $\mathrm{Si}$ Hyoung $\mathrm{Oh}$ 그룹의 연구결과는 방전과정에서 형성되는 $\mathrm{ZnMn}_{3} \mathrm{O}_{7} \cdot 3 \mathrm{H}_{2} \mathrm{O}$ ( $\mathrm{Zn}$-buserite)에 기초한 전기화학 반 응 메커니즘과 방전 반응 동안 $\alpha-\mathrm{MnO}_{2}$ 의 표면에 석출되 는 $\mathrm{Zn}_{4}(\mathrm{OH})_{6}\left(\mathrm{SO}_{4}\right) \cdot 5 \mathrm{H}_{2} \mathrm{O}$ (Zinc hydroxide sulfate)에 기인한다고 주장하고 있다. ${ }^{17-19)}$ 보다 자세한 설명으로, $\alpha-\mathrm{MnO}_{2}$ 의 충 · 방전 용량은 전극표면에서의 $\mathrm{Zn}_{4}(\mathrm{OH})_{6}$ $\left(\mathrm{SO}_{4}\right) \cdot 5 \mathrm{H}_{2} \mathrm{O}$ (Zinc hydroxide sulfate) 석출 - 용해에 기인하며, 이 hydroxide sulfate의 형성조건은 $\mathrm{Mn}^{3+}$ 의 불균등화 반응과 전기화학 반응 동안 전해질로의 $\mathrm{Mn}^{2+}$ 이온의 용해에 의한 $\mathrm{pH}$ 의 급격한 변화가 관련이 있다고 해석하였다. 결과적으로 연속되는 충 - 방전 과정에서 비 가역적 용량 손실이 최소화됨으로써 전체 반응이 가역적 으로 발생한다고 주장하였다. Jun Liu 그룹도 앞선 그룹 들과 다른 전기화학 반응 메커니즘을 제시하였으며, 이는 $2 \mathrm{M} \mathrm{ZnSO}_{4}$ 전해질과 $\alpha-\mathrm{MnO}_{2}$ 를 양극으로 활용한 $\mathrm{Zn} / /$ $\alpha-\mathrm{MnO}_{2}$ 전지를 통해 증명하였다. ${ }^{20)}$ 이 그룹에서 제시하 는 메커니즘은 방전 반응 동안 형성되는 $\mathrm{MnOOH}$ 에 의해 발생하는 양성자 삽입에 의한 변환 반응 메커니즘이다. 이로 인한 전기화학 특성 결과로 $154 \mathrm{~mA} \mathrm{~g}^{-1}$ 의 전류밀도 (a)

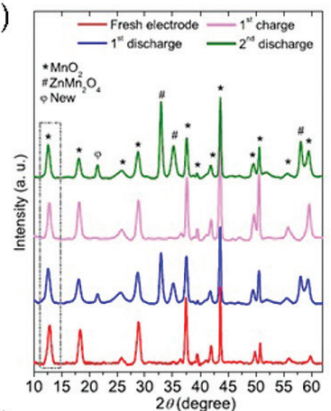

(b)

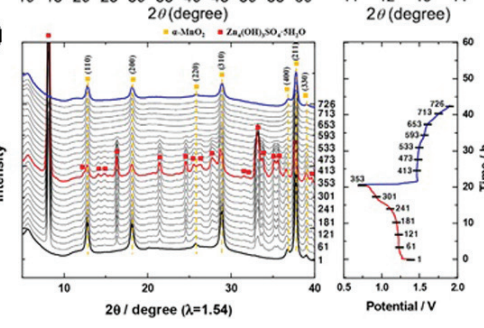

(c)
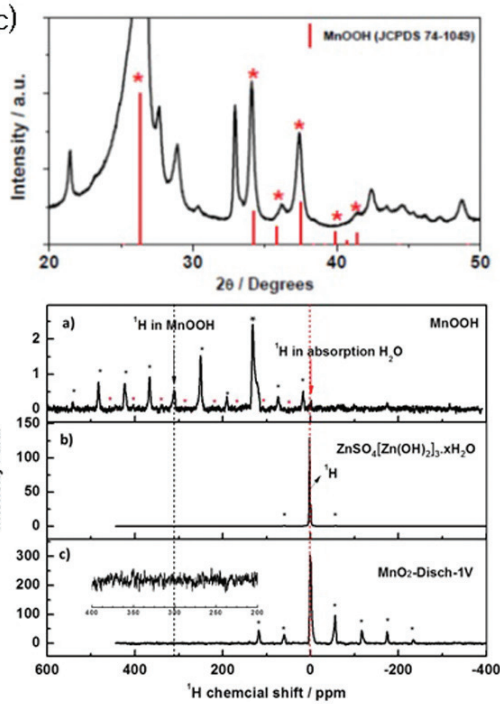

Fig. 5. Evidence of electrochemical reaction mechanism of $\alpha-\mathrm{MnO}_{2}$ cathode in Zinc ion battery (a) formation of $\mathrm{ZnMn}_{2} \mathrm{O}_{4}{ }^{15,16)}$, (b) formation of Zinc hydrosulfate ${ }^{17-19)}$, (c) formation of $\mathrm{MnOOH}^{20)}$ 
조건에서 $210 \mathrm{mAh} \mathrm{g}^{-1}$ 의 높은 방전용량을 발현하며, 평 균 작동전압은 $1.44 \mathrm{~V}$ 로 나타남을 확인하였다. 초기 약산 성 전해질을 활용한 $\mathrm{Zn} / / \alpha-\mathrm{MnO}_{2}$ 전지에서 이와 같은 부산물 형성이 보고되지 않았다는 것을 고려했을 때, $\mathrm{MnOOH}$ 형성에 의한 양성자 삽입 변환 메커니즘은 전해 질 내 높은 염 농도 및 전기 화학 반응 동안 전해질의 급 격한 $\mathrm{pH}$ 변화와 연관이 있다고 주장하였다. (Fig. 5.)

초기 활발하게 연구된 $\alpha-\mathrm{MnO}_{2}$ 외에 망간계 산화물의 동질이상체인 터널구조의 $\beta, \gamma-\mathrm{MnO}_{2}$, 층상구조의 $\delta-\mathrm{MnO}_{2}$, 스피넬 구조의 $\lambda-\mathrm{MnO}_{2}$ 등에 대한 연구가 최 근 진행되었으며, 이에 대한 연구결과 및 각 소재 별 전기 화학 반응 메커니즘은 다음과 같다.

Jaekook Kim 그룹은 $\alpha-\mathrm{MnO}_{2}$ 외에도 망간 산화물의 동질이상체인 터널 구조의 $\gamma-\mathrm{MnO}_{2}$ 와 층상구조의 $\delta-\mathrm{MnO}_{2}$ 를 아연 이온 이차전지의 양극으로 적용한 연구 를 진행하였다. ${ }^{21,22)}$ 이에 대한 전기화학 반응 메커니즘을 분석하기 위하여 in-situ X-ray diffraction(XRD)와 $\mathrm{X}$-ray Absorption Spectroscopy(XAS)를 분석한 결 과, 스피넬 구조의 $\mathrm{ZnMn}_{2} \mathrm{O}_{4}$ 만 형성되는 $\alpha-\mathrm{MnO}_{2}$ 와 다 르게 스피넬 구조의 $\mathrm{ZnMn}_{2} \mathrm{O}_{4}\left(\mathrm{Mn}^{3+}\right)$ 와 새로운 2개의 중 간상을 통해 전기화학 반응이 이루어짐을 확인하였다. 새
로운 2개의 중간상은 터널 구조의 $\gamma-\mathrm{Zn}_{\mathrm{x}} \mathrm{MnO}_{2}\left(\mathrm{Mn}^{2+}\right)$ 와 층상구조의 $\mathrm{Zn}_{\mathrm{y}} \mathrm{MnO}_{2}\left(\mathrm{Mn}^{2+}\right)$ 으로 충 · 방전 과정에서 $\mathrm{ZnMn}_{2} \mathrm{O}_{4}$ 와 같이 가역적인 구조변형이 발생하는 것을 확 인하였다. 터널구조의 $\gamma-\mathrm{MnO}_{2}$ 와 층상구조의 $\delta-\mathrm{MnO}_{2}$ 양극 소재를 적용한 전지의 초기 방전용량은 $285 \mathrm{mAh}$ $\mathrm{g}^{-1}\left(0.05 \mathrm{~mA} \mathrm{~cm}^{-2}\right)$ 및 $252 \mathrm{mAh} \mathrm{g}^{-1}\left(83 \mathrm{~mA} \mathrm{~g}^{-1}\right)$ 로 각각 높은 방전용량을 발현하였으나 반복되는 충 - 방전에 따 라 급격한 용량감소가 발생하는 것을 확인하였다. 이는 $\mathrm{Mn}^{2+}$ 에 기반을 둔 중간상 구조가 전해질로의 망간 용해 로 인한 구조 붕괴와 관련이 있다고 주장하였다.

Jun Chen 그룹은 모든 터널 구조의 $\mathrm{MnO}_{2}(\alpha, \beta, \gamma)$ 소 재와 $3 \mathrm{M} \mathrm{Zn}\left(\mathrm{CF}_{3} \mathrm{SO}_{3}\right)_{2}$ 수용성 전해질을 활용한 $\mathrm{Zn} / / \alpha$, $\beta, \gamma-\mathrm{MnO}_{2}$ 전지를 통해 동질이상체인 $\alpha, \beta, \gamma-\mathrm{MnO}_{2}$ 가 공통적인 전기화학 반응 메커니즘을 갖는다고 주장하였 다. ${ }^{23)}$ 자세하게는 초기 아연 이온이 삽리 됨에 따라 터널 구조에서 층상구조 $\left(\mathrm{Zn}\right.$-buserite, $\left.\beta-\mathrm{Zn}_{\mathrm{x}} \mathrm{MnO}_{2} \cdot \mathrm{H}_{2} \mathrm{O}\right)$ 로 변형이 발생하며, 이후 반응에서는 $\mathrm{Zn}$-buserite구조 가 유지되는 메커니즘이다. 이러한 상 변이는 $\beta-\mathrm{MnO}_{2}$ 를 양극으로 적용한 전지에서 $225 \mathrm{mAh} \mathrm{g}^{-1}$ 의 높은 용량을 발현하는데 기여하였다. 하지만, 주장하는 메커니즘과 달리 초기 방전 이후 약간의 $\beta-\mathrm{MnO}_{2}$ 구조가 유지되는 현 (a)

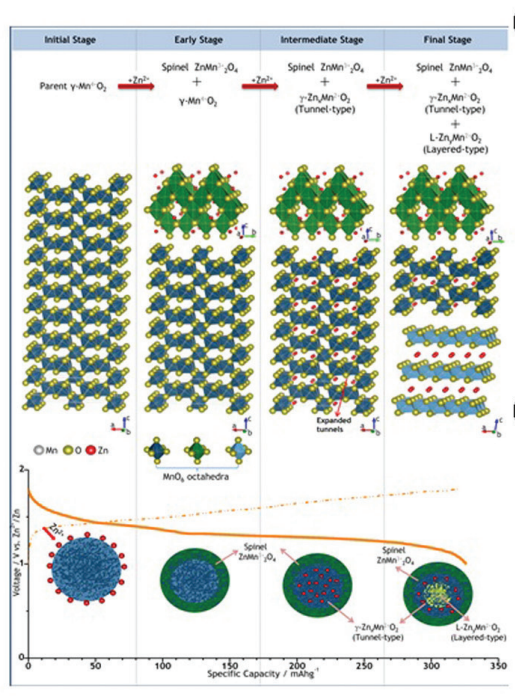

(b)
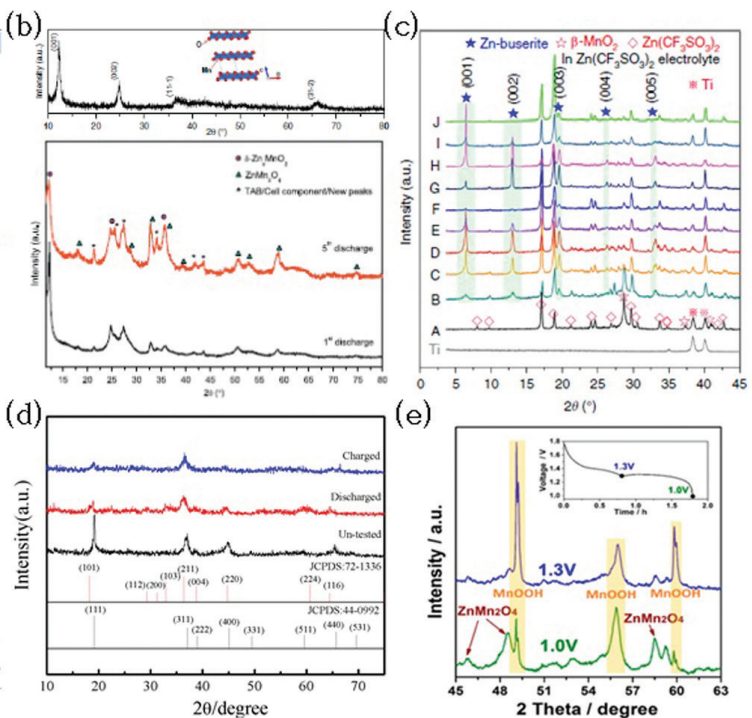

(e)

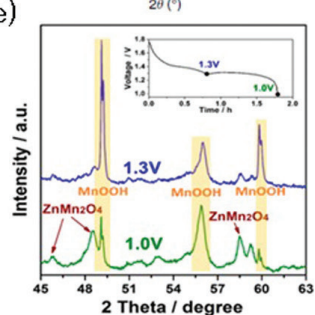

Fig. 6. Schematic and evidence of Electrochemical reaction mechanism of $\mathrm{MnO}_{2}$ cathode in Zinc ion battery (a) $\gamma-\mathrm{MnO}_{2}{ }^{211}$, (b) $\delta-\mathrm{MnO}_{2}{ }^{22)}$, (c) $\beta-\mathrm{MnO}_{2}^{23)}$, (d) $\lambda-\mathrm{MnO}_{2}^{25)}$, (e) $\varepsilon-\mathrm{MnO}_{2}^{27)}$ 
상을 확인하였으며 이는 $\beta-\mathrm{MnO}_{2}$ 가 미량의 아연 이온을 수용할 수 있는 가능성을 원인으로 제시하였다. 이와 동 일한 메커니즘을 주장하는 Jaekook Kim 그룹에서는 $2 \mathrm{M} \mathrm{ZnSO}_{4}$ 전해질 조건에서 $\beta-\mathrm{MnO}_{2}$ 를 양극으로 활용 한 $\mathrm{Zn} / / \beta-\mathrm{MnO}_{2}$ 전지를 통해 증명하였다. 이 그룹에서는 전기화학 반응 메커니즘 분석을 통해 $\beta-\mathrm{MnO}_{2}$ 구조에 아 연 이온의 수용가능성을 증명하였다. ${ }^{24)}$ 전기화학 평가 결 과로 $100 \mathrm{~mA} \mathrm{~g}^{-1}$ 의 전류밀도 조건에서 $270 \mathrm{mAh} \mathrm{g}^{-1}$ 으로 높은 방전용량 특성을 발현하였다.

Dianxue Cao 그룹은 스피넬 구조의 $\lambda-\mathrm{MnO}_{2}$ 를 아연 이온 이차전지의 양극으로 적용한 연구를 발표하였다, ${ }^{25}$ 그 결과, Jun Chen 그룹에서 발표한 결과 중 아연 이온 삽 · 탈리에 따른 스피넬 구조의 $\mathrm{ZnMn}_{2} \mathrm{O}_{4}$ 의 구조 유지 ${ }^{26)}$ 와 같이 $\lambda-\mathrm{MnO}_{2}$ 구조에서도 아연 이온의 반복적인 삽 . 탈리 동안 구조가 유지됨을 확인하였다.

Chunsheng Wang 그룹에서는 동질이소체 중 터널이 나 스피넬, 층상구조가 아닌 $\varepsilon-\mathrm{MnO}_{2}$ 를 아연 이온 이차 전지의 양극에 적용한 결과, $90 \mathrm{~mA} \mathrm{~g}^{-1}$ 의 전류밀도 조건 에서 $290 \mathrm{mAh} \mathrm{g}^{-1}$ 의 우수한 용량 특성 및 $6.5 \mathrm{C}$ 의 높은 전류밀도 조건에서 10,000 회의 충 · 방전 동안 우수한 용 량유지 특성을 발현함을 확인하였다. ${ }^{27)}$ 이에 대한 전기화 학 반응 메커니즘을 분석한 결과, 아연 이온과 수소 이온 이 삽 · 탈리 됨에 따른 $\mathrm{MnOOH}$ 및 $\mathrm{ZnMn}_{2} \mathrm{O}_{4}$ 의 형성 및 분해에 의한 전기화학 반응이 발생함을 확인하였다. (Fig. 6.)

앞서 언급한 많은 그룹에서 규명한 $\mathrm{MnO}_{2}$ 의 전기화학
반응 메커니즘은 전반적으로 $\mathrm{MnO}_{2}$ 의 동질이상체에 따른 구조, 전해질의 $\mathrm{pH}$ 또는 입자 형상과 같은 변수에 따라 다르게 나타난다. 통상적으로 망간 산화물계 소재는 충 방전 중 전극으로부터 전해질로 $\mathrm{Mn}^{2+}$ 이온의 용해가 발생 하고 이에 따른 낮은 전도도 특성으로 급격한 용량 감소 가 발생한다. 이를 억제하기 위해 다양한 연구가 진행되 었으며, 다음과 같은 방법으로 개선할 수 있다.

먼저 Jun Liu 그룹의 연구에서는 $2 \mathrm{M} \mathrm{ZnSO}_{4}$ 의 수용성 전해질에 $\mathrm{MnSO}_{4}\left(\mathrm{Mn}^{2+}\right)$ 염을 추가, 이를 통해 전해질 내 $\mathrm{Mn}^{2+}$ 이온의 농도를 높여 충 - 방전 과정에서 발생하는 $\mathrm{Mn}^{2+}$ 이온의 용해를 억제하여 성능개선이 가능함을 제시 하였다. ${ }^{20)}$

또한, 탄소 나노 튜브(CNT) 또는 그래핀과 같은 탄소 계 물질을 소재에 코팅하거나 원소 도핑을 통해 $\mathrm{MnO}_{2}$ 소 재의 전도도를 향상시킬 수 있는데, Liqiang Mai 그룹에 서는 그래핀을 $\alpha-\mathrm{MnO}_{2}$ 에 스크롤 코팅하여 3,000회 충 - 방전 이후 초기방전 용량 대비 $94 \%$ 의 용량을 유지하 여 그래핀 코팅을 통한 장기 수명 특성 향상을 확인하였 다. ${ }^{28)} \mathrm{Jaekook} \mathrm{Kim}$ 그룹에서는 $\alpha-\mathrm{MnO}_{2}$ 에 이종 전이금 속인 바나듐 $(\mathrm{V})$ 을 도핑 하여 순수 $\alpha-\mathrm{MnO}_{2}$ 에 비해 약 $31 \%$ 향상된 용량특성 발현과 수명특성 향상을 확인하였 다. ${ }^{29)}$ (Fig. 7.)

최근 학계에서는 아연 이온 이차전지의 새로운 양극소 재로 todorokite $\mathrm{MnO}_{2}, \alpha-\mathrm{Mn}_{2} \mathrm{O}_{3}$ 및 $\mathrm{Mn}_{3} \mathrm{O}_{4}$ 와 같은 기 타 망간계 산화물의 아연 이온 이차전지 적용에 대한 연 구를 진행하고 있다. Si Hyoung $\mathrm{Oh}$ 그룹은 앞선 $2 \times 2$ (a)

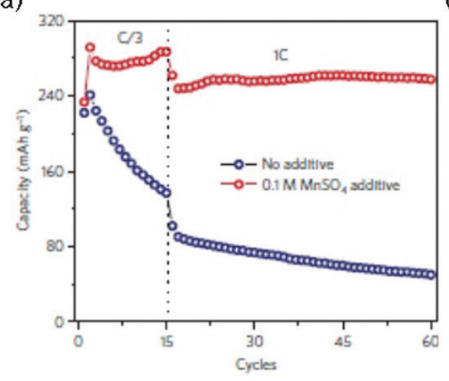

(b)

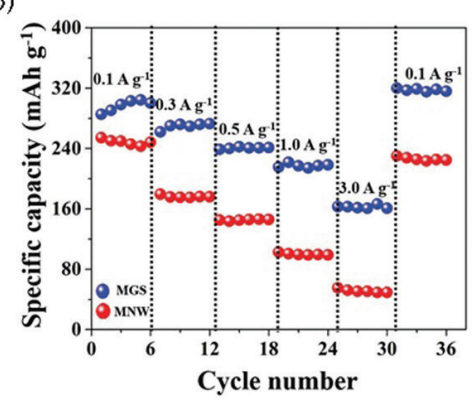

(c)

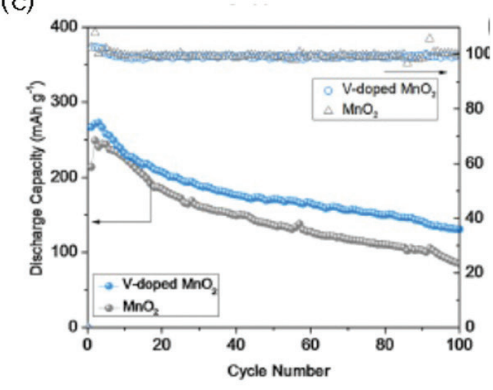

Fig. 7. Evidence of improvement electrochemical reaction $\mathrm{MnO}_{2}$ cathode in Zinc ion battery by (a) $\mathrm{MnSO}_{4}$ additive ${ }^{20}$, (b) Graphene coating $^{28)}$, (c) Vanadium doping ${ }^{29)}$ 
터널 구조를 갖는 $\alpha-\mathrm{MnO}_{2}$ 보다 큰 $3 \times 3$ 터널구조의 todorokite $\mathrm{MnO}_{2}$ 를 아연 이온 이차전지의 양극재로 활 용하여 보다 빠른 아연 이온의 확산을 유도하였으며, 이 양극을 적용한 전지는 $98 \mathrm{mAh} \mathrm{g}^{-1}$ 의 방전용량 특성발현 과 50 회 이상의 반복되는 충 · 방전에서 안정된 수명특성 발현하는 것을 확인하였다. ${ }^{30)}$ Feiyu Kang 그룹에서는 $\alpha-\mathrm{Mn}_{2} \mathrm{O}_{3}$ 를 아연 이온 이차전지의 양극재로 활용하여 $148 \mathrm{mAh} \mathrm{g}^{-1}$ 방전용량 특성 발현과 $2 \mathrm{~A} \mathrm{~g}^{-1}$ 의 전류밀도 조건에서 1,000 회 충 · 방전 후에도 $82.2 \mathrm{mAh} \mathrm{g}^{-1}$ 의 용량 특성 발현을 통해 안정된 수명특성을 확인하였다. ${ }^{31)}$ 추가 적으로 Feiyu Kang 그룹에서는 스피넬 구조의 $\mathrm{Mn}_{3} \mathrm{O}_{4}$ 를 아연 이온 이차전지의 양극재로 활용하여 $0.2 \mathrm{~A} \mathrm{~g}^{-1}$ 의 전 류밀도 조건에서 $232 \mathrm{mAh} \mathrm{g}^{-1}$ 의 방전 용량 특성을 발현 하는 것을 확인하였으며, 보다 높은 $0.5 \mathrm{~A} \mathrm{~g}^{-1}$ 의 전류밀도 조건에서 300회 충 · 방전 이후 $106.1 \mathrm{mAh} \mathrm{g}^{-1}$ 의 용량특 성 발현을 통해 우수한 수명특성을 확인하였다. ${ }^{22)}$ 이와 같이 새로운 망간계 산화물 양극소재는 아연 이온 배터리 의 양극소재 적용 가능성을 보여주고 있으며, 이에 대한 추가연구가 필요한 시점이다.

이와 관련하여 최근 발생하고 있는 이차전지의 폭발사 고와 관련하여 안정성 향상을 위해 추구되고 있는 전고체 전지(All Solid-state battery)를 망간계 산화물 양극소 재가 적용된 아연 이온 이차전지에 적용한 연구가 주목받 고 있다. 특히 전고체 아연 이온 이차전지는 독성이 없으 며, 저렴하며, 매우 안전한 특성으로 높은 잠재력을 지니 고 있기에 이에 대한 개발이 절대적으로 필요하다.

Chunyi Zhi 그룹에서는 전기 방사를 활용하여 합성한 polyacrylonitrile(PAN)의 기공을 가교 결합된 gelatin$\mathrm{g}$-polyacrylamide(PAM) 겔을 활용하여 채운 교차 계 층적 폴리머 전해질 $(\mathrm{HPE})$ 을 개발했다. ${ }^{33)}$ 이 전해질의 전 기화학 특성을 확인하기 위하여 나노 크기의 수지상 입자 인 $\alpha-\mathrm{MnO}_{2}$ 를 양극으로 활용하고 산 처리된 탄소나노튜 브(CNT)위에 증착된 아연 금속을 음극으로 활용한 전지 의 전해질로 사용하여 전고체 전지를 구성하였다. 이를 통해, 아연 이온의 가역적인 삽 - 탈리를 확인하였으며, 전기화학 특성 평가결과 $1 \sim 1.8 \mathrm{~V}$ 의 전압범위에서 $306 \mathrm{mAh} \mathrm{g}^{-1}$ 의 높은 방전 용량 특성을 발현하였으며,
1,000 회의 충 - 방전 이후 $97 \%$ 의 용량유지를 보였다. 또 한 $6.18 \mathrm{mWh} \mathrm{cm}^{-2}$ 의 단위 면적 당 높은 에너지 밀도와 $148.2 \mathrm{~mW} \mathrm{~cm}^{-2}$ 의 높은 출력밀도를 발현함을 확인하였 다. 이를 통해 $\mathrm{HPE}$ 전해질의 높은 아연 이온 전도성, 유 연성, 기계적 강도를 증명하였다.

Yexiang Tong 그룹에서는 $\mathrm{MnO}_{2} @ \mathrm{PEDOT}$ 을 양극으 로 활용하고 아연 금속을 음극 활용한 전지에 기존 PVA 에서 변형된 $\mathrm{PVA} / \mathrm{ZnCl}_{2} / \mathrm{MnSO}_{4}$ 의 젤 전해질을 활용하 여 준-전고체 전지를 구성하였다. ${ }^{34)}$ 이 전지의 전기화학 특성 평가 결과 $504.9 \mathrm{Wh} \mathrm{kg}-1$ 의 우수한 에너지 밀도 특 성과 $8.6 \mathrm{~kW} \mathrm{~kg}^{-1}$ 의 우수한 출력밀도, 300 회 충 · 방전 이후 거의 $100 \%$ 에 달하는 용량특성을 발현하여 높은 수 명특성을 확인하였다.

\subsection{2바나듐계 양극소재}

바나듐 $(\mathrm{V})$ 은 저렴한 가격 $(2.5 \$ / \mathrm{lb})$ 으로 전기화학 소 재 분야에 새로운 관심을 불러 일으켰고 현재는 아연 이 온 이차전지에서도 양극 소재로의 적용을 시도하고 있다. 바나듐 산화물은 일반적으로 전자적 특성과 자기적 특성 을 모두 가지고 있으며, 바나듐 주위의 산소 배위수와 이 에 따른 구조에 의해 $\mathrm{V}^{2+}$ 에서 $\mathrm{V}^{5+}$ 의 광범위한 산화가를 갖는 것으로 알려져 있다. 이렇듯 대부분의 바나듐 산화 물은 다중 산화 상태, 배위 다면체 및 금속-산소 연결성 으로 인해 층상구조 및 개방형 네트워크 구조를 가지며 풍부한 결정 화학을 보유하고 있어 아연 이온 이차전지의 양극 소재 후보로 각광받고 있다.

Linda F. Nazar 그룹에서는 처음으로 바나듐 산화물 을 아연 이온 이차전지의 양극으로 적용하였다. ${ }^{35)}$ 그 소 재는 $\mathrm{Zn}_{0.25} \mathrm{~V}_{2} \mathrm{O}_{5} \cdot \mathrm{nH}_{2} \mathrm{O}$ 이며, 이에 대한 전기화학 특성 평가를 진행한 결과, $15 \mathrm{C}$ 의 매우 높은 전류밀도 조건에서 250 300 $\mathrm{mAh} \mathrm{g}^{-1}$ 의 높은 용량특성을 발현하였으며, $0.81 \mathrm{~V}$ 의 평균 전압을 갖는 것을 확인하였다. 또한 1,000 회의 충 - 방전 이후에도 매우 우수한 용량을 발현함을 확 인하였다. 이 소재의 전기화학 반응 메커니즘을 규명하기 위하여 in-situ X-ray Diffraction(XRD)를 분석한 결 과, 층상구조인 $\mathrm{V}_{2} \mathrm{O}_{5}$ 내 아연 이온 $\left(\mathrm{Zn}^{2+}\right)$ 과 물 $\left(\mathrm{H}_{2} \mathrm{O}\right)$ 분자 가 전기화학 반응에서 층상구조 내 채널을 가역적으로 확 


\section{특 집 미 조정근, 김재국}

장 및 축소시켜 아연 이온의 삽 - 탈리를 수월하게 하며, 이에 따른 우수한 동역학 및 율속 특성을 이끌어냄을 확 인하였다.

이러한 메커니즘을 바탕으로 층상구조인 $\mathrm{V}_{2} \mathrm{O}_{5}$ 의 이온 확산 속도 및 전자 전도성을 향상 시키기 위해 기둥역할 을 하는 다양한 금속이온의 효과에 대한 연구가 진행되고 있다. Liqiang Mai 그룹에서는 소듐 이온 $\left(\mathrm{Na}^{+}\right)$이 기둥 역할을 하는 소재인 $\mathrm{Na}_{0.33} \mathrm{~V}_{2} \mathrm{O}_{5}$ 에 대한 연구결과를 발표 하였다. ${ }^{36)} 3 \mathrm{M} \mathrm{Zn}\left(\mathrm{CF}_{3} \mathrm{SO}_{3}\right)_{2}$ 전해질을 활용하여 전지를 구성하였으며 전기화학 특성 평가결과 $0.1 \mathrm{~A} \mathrm{~g}^{-1}$ 의 높은 전류밀도 조건에서 $367 \mathrm{mAh} \mathrm{g}^{-1}$ 의 우수한 용량 특성을 발현하였다. 1,000 회의 충 - 방전 이후 초기 방전 용량 대 비 $93 \%$ 의 용량을 유지하여 우수한 수명특성도 확인하였
다. 전기화학 반응 메커니즘을 확인하기 위해 X-ray Diffraction(XRD)와 Raman Spectroscopy 및 X-ray Photoelectron Spectroscopy(XPS)를 활용하였다. 그 결과 소듐 이온이 층상구조의 $\mathrm{V}_{2} \mathrm{O}_{5}$ 내에서 기둥역할을 하여 구조가 안정적으로 유지됨을 확인하였으며 이에 따 른 수명특성이 향상됨을 증명하였다.

Husam N. Alshareef 그룹에서는 칼슘이온 $\left(\mathrm{Ca}^{2+}\right)$ 이 기둥역할을 하는 소재인 $\mathrm{Ca}_{0.25} \mathrm{~V}_{2} \mathrm{O}_{5} \cdot \mathrm{nH}_{2} \mathrm{O}$ 에 대한 연구 결과를 발표하였다. ${ }^{37)}$ 전기화학 특성 평가 결과 $0.2 \mathrm{C}$ 의 전류밀도 조건에서 $340 \mathrm{mAh} \mathrm{g}^{-1}$ 의 높은 용량 특성과 $80 \mathrm{C}$ 의 매우 높은 전류밀도에서 3,000회의 충 · 방전 이 후 초기 방전용량 대비 $96 \%$ 의 용량 유지 특성을 발현하 는 것을 확인하였다.

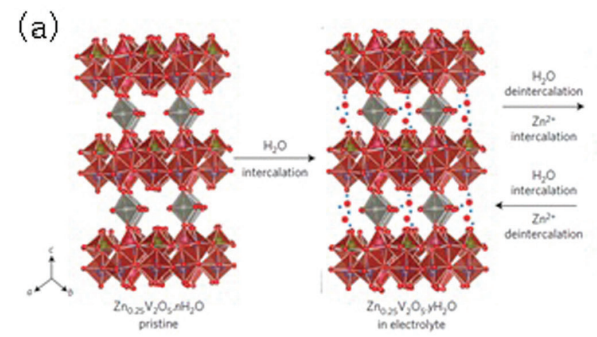

(b)

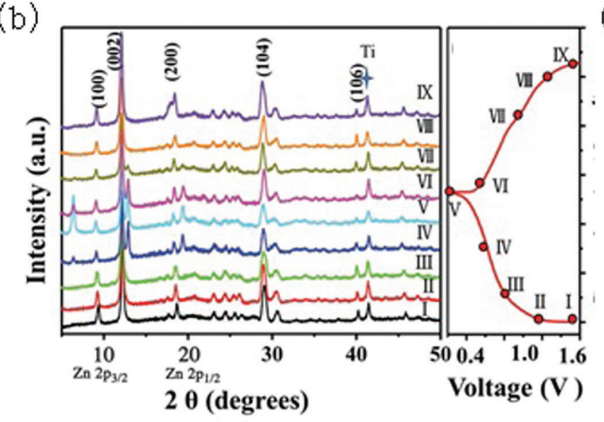

(d)

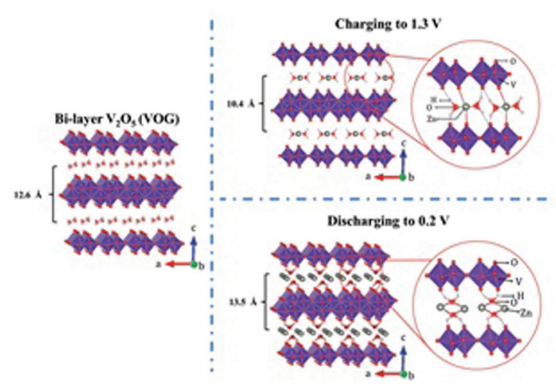

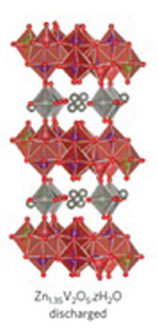

(c)
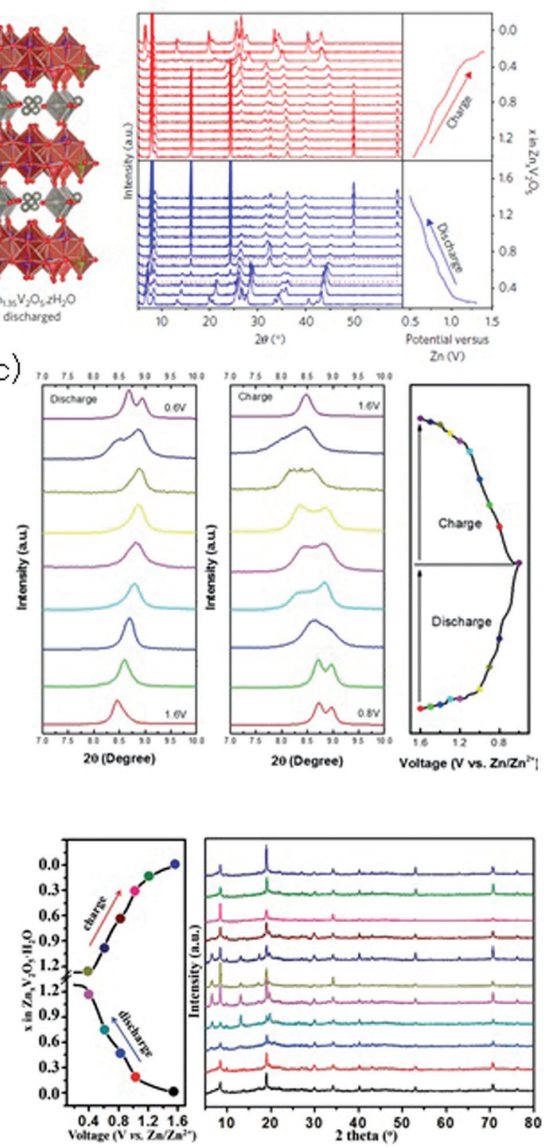

Fig. 8. Schematic and evidence of electrochemical reaction mechanism of $\mathrm{V}_{2} \mathrm{O}_{5}$ cathode in Zinc ion battery (a) $\mathrm{Zn}_{0.25} \mathrm{~V}_{2} \mathrm{O}_{5} \cdot \mathrm{nH}_{2} \mathrm{O}^{35}$, (b) $\mathrm{Na}_{0.33} \mathrm{~V}_{2} \mathrm{O}_{5}{ }^{36}$, (c) $\mathrm{Ca}_{0.25} \mathrm{~V}_{2} \mathrm{O}_{5}{ }^{37)}$, (d) $\mathrm{V}_{2} \mathrm{O}_{5} \cdot \mathrm{nH}_{2} \mathrm{O}^{38)}$ 
Jihui Yang 그룹에서는 $\mathrm{V}_{2} \mathrm{O}_{5} \cdot \mathrm{nH}_{2} \mathrm{O}$ 의 물 분자가 아 연 이온 이차전지의 구조 안정성과 우수한 전기화학 성능 발현에 결정적인 역할을 한다는 연구결과를 발표하였 다. ${ }^{38)}$ 이는 Linda F. Nazar 그룹에서 발표한 내용5) 보다 자세한 메커니즘을 설명한 연구결과로 물 $\left(\mathrm{H}_{2} \mathrm{O}\right)$ 분자와 전해질에 존재하는 아연 이온은 아주 미세한 유효전하를 가지고 있어 $\mathrm{V}_{2} \mathrm{O}_{5}$ 구조의 정전기적 상호작용을 크게 억제 하여 확산을 촉진한다고 주장하였다. 이와 같이 물 $\left(\mathrm{H}_{2} \mathrm{O}\right)$ 분자는 $\mathrm{V}_{2} \mathrm{O}_{5}$ 구조 내에서 윤활제와 같은 효과를 발현하 며 이는 전기화학 반응 중 $6.4 \mathrm{~kW} \mathrm{~kg}^{-1}$ 의 높은 출력밀도 에서 $90 \mathrm{Wh} \mathrm{kg}^{-1}$ 의 에너지 밀도를 발현하는데 기여하였 다. (Fig. 8.)

앞선 결과들을 통해 Linda F. Nazar 그룹에서 규명한 메커니즘이 아연 이온이 아닌 다른 이온 즉, 소듐과 칼슘 이온에도 적용 가능함을 확인하였으며, 기둥역할을 하는 소듐, 칼슘 이온 및 물 분자가 전기화학 반응 중에 층상구 조의 $\mathrm{V}_{2} \mathrm{O}_{5}$ 구조유지를 유도하여 우수한 전기화학 특성 발현함을 확인하였다. 이와 같은 소재들은 고성능, 저비 용, 우수한 안정성 및 환경 친화적이라는 특성으로 대용 량 에너지 저장장치의 차세대 소재로서 유망한 후보로 주 목받고 있다.

Jaekook Kim 그룹에서는 리튬 이온 이차전지에서 적 용되었던 층상구조의 $\mathrm{LiV}_{3} \mathrm{O}_{8}$ 을 아연 이온 이차전지의 양 극소재로 적용한 연구결과를 발표하였다. ${ }^{39)}$ 층상구조인 $\mathrm{LiV}_{3} \mathrm{O}_{8}$ 은 $\mathrm{VO}_{6}$ 팔면체와 $\mathrm{VO}_{5}$ bi-pyramid 삼방정계가 (100)면을 따라 형성한 $\mathrm{V}_{3} \mathrm{O}_{8}$ 층과 팔면체와 사면체 사이 에 있는 리튬 이온에 의해 각 층들이 연결된 구조로서 앞 서 언급한 것과 같이 리튬 이온과 아연 이온은 거의 비슷 한 이온 반경을 가져 아연 이온의 가역적인 삽 - 탈리가 가능할 것으로 예상하였다. 이를 확인하기 위하여 아연 이온 이차전지의 양극 소재로 $\mathrm{LiV}_{3} \mathrm{O}_{8}$ 를 적용하였으며, $0.6 \sim 1.2 \mathrm{~V}$ 의 전압범위에서 $133 \mathrm{~mA} \mathrm{~g}^{-1}$ 의 전류밀도 조건 으로 전기화학 특성평가를 진행한 결과 $172 \mathrm{mAh} \mathrm{g}^{-1}$ 의 방전용량 특성을 발현하는 것을 확인하였다. 이러한 전기 화학 반응의 메커니즘을 규명하기 위하여 In-situ $\mathrm{X}$-ray Diffraction(XRD)분석을 진행하였으며, 3단계 반응에 걸쳐 방전 반응이 발생함을 확인하였다. 1단계에
서는 아연 이온이 $\mathrm{LiV}_{3} \mathrm{O}_{8}$ 구조 내 채워진 리튬과 다른 에 너지를 갖는 비어 있는 리튬 자리를 차지하기 시작하여 $\mathrm{ZnLiV}_{3} \mathrm{O}_{8}$ 상이 단일상 반응으로 형성됨을 확인하였다. 2 단계에서는 아연 이온 삽입에 따라 (100)면에 해당하는 피크의 분할이 나타나는 것을 통해 $\mathrm{LiV}_{3} \mathrm{O}_{8}$ 과 $\mathrm{ZnLiV}_{3} \mathrm{O}_{8}$ 의 2 상 반응이 나타남을 확인하였다. 마지막 3 단계에서 는 아연 이온 삽입에 따라 다시 단일 상 반응이 나타났고 이를 통해 $\mathrm{Zn}_{\mathrm{y}} \mathrm{LiV}_{3} \mathrm{O}_{8}(\mathrm{y}>1)$ 이 형성됨을 확인하였다. 반 대로 충전반응에서는 아연 이온의 탈리 에 따라 $\mathrm{Zn}_{\mathrm{y}} \mathrm{LiV}_{3} \mathrm{O}_{8}$ 에서 단일상 반응을 통해 $\mathrm{LiV}_{3} \mathrm{O}_{8}$ 으로 회복됨 을 확인하였다. 이 결과는 기존에 보고되었던 $\mathrm{LiV}_{3} \mathrm{O}_{8}$ 의 리튬 이온 삽 - 탈리에 따른 메커니즘과 상이하게 나타났 으며 이는 층상구조 소재의 전기화학 반응 중 상변화를 이해하는 새로운 접근방법을 제시하였으며 아연 이온 이 차전지의 양극소재로 $\mathrm{LiV}_{3} \mathrm{O}_{8}$ 의 적용 가능성을 보여주고 있다.

Liqiang Mai 그룹에서는 $\mathrm{V}_{3} \mathrm{O}_{8}$ 층 사이에 리튬 이온이 자리한 $\mathrm{LiV}_{3} \mathrm{O}_{8}$ 과 달리 수소 이온이 자리한 $\mathrm{H}_{2} \mathrm{~V}_{3} \mathrm{O}_{8}$ 을 아 연 이온 이차전지의 양극소재로 적용한 연구결과를 발표 하였다. ${ }^{40)} 3 \mathrm{M} \mathrm{Zn}\left(\mathrm{CF}_{3} \mathrm{SO}_{3}\right)_{2}$ 전해질을 활용하여 전지를 구성하였으며 $0.2 \sim 1.6 \mathrm{~V}$ 의 전압범위에서 전기화학 특성 평가를 진행하였다. 그 결과, $0.1 \mathrm{~mA} \mathrm{~g}^{-1}$ 의 전류밀도 조 건에서 $424 \mathrm{mAh} \mathrm{g}^{-1}$ 의 높은 용량특성을 발현하며 $5 \mathrm{~A} \mathrm{~g}^{-1}$ 의 높은 전류밀도 조건에서 1,000 회 충 · 방전 이후 초기 용량 대비 $94 \%$ 의 용량특성을 유지하는 것을 확인하였다.

추가적으로 Liqiang Mai 그룹에서는 $\mathrm{V}_{3} \mathrm{O}_{8}$ 층 사이에 존재하는 이온에 의한 구조적 안정성 향상을 위해 소듐 이온이 자리한 $\mathrm{Na}_{2} \mathrm{~V}_{6} \mathrm{O}_{16} \cdot 1.63 \mathrm{H}_{2} \mathrm{O}$ 을 아연 이온 이차전 지의 양극소재로 적용한 연구결과도 발표하였다. ${ }^{41}$ $\mathrm{Zn}\left(\mathrm{CF}_{3} \mathrm{SO}_{3}\right)_{2}$ 전해질을 활용하여 전지를 구성하였으며 0.2 1.6V의 전압범위에서 전기화학 특성평가를 진행하 였다. 그 결과, $50 \mathrm{~mA} \mathrm{~g}^{-1}$ 의 전류밀도 조건에서 $352 \mathrm{mAh}$ $\mathrm{g}^{-1}$ 의 높은 용량특성을 발현하였으며 $5 \mathrm{~A} \mathrm{~g}^{-1}$ 의 높은 전류 밀도 조건에서 6,000 회의 충 - 방전 이후 초기 용량 대비 $90 \%$ 의 용량이 유지됨을 확인하였다. 앞선 연구 결과들을 통해 $\mathrm{V}_{3} \mathrm{O}_{8}$ 층상구조를 포함하는 $\mathrm{M}_{\mathrm{x}} \mathrm{V}_{\mathrm{n}} \mathrm{O}_{\mathrm{m}}(\mathrm{M}=\mathrm{H}, \mathrm{Li}, \mathrm{Na}$ 등 기타 금속 이온)은 각 층 사이에 위치한 금속 이온에 
(a)

(b)

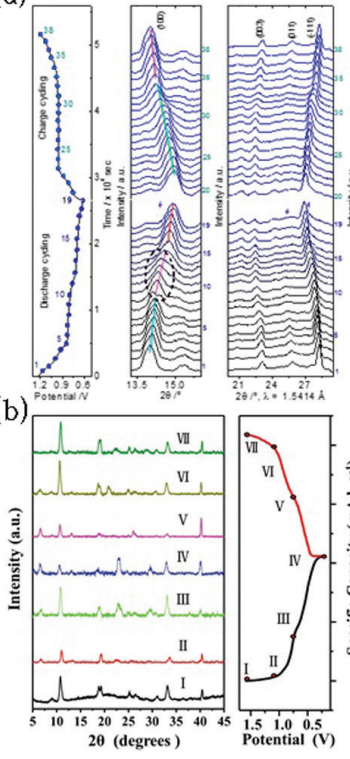

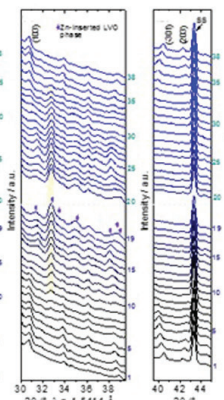

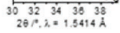

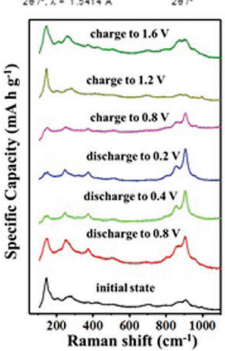

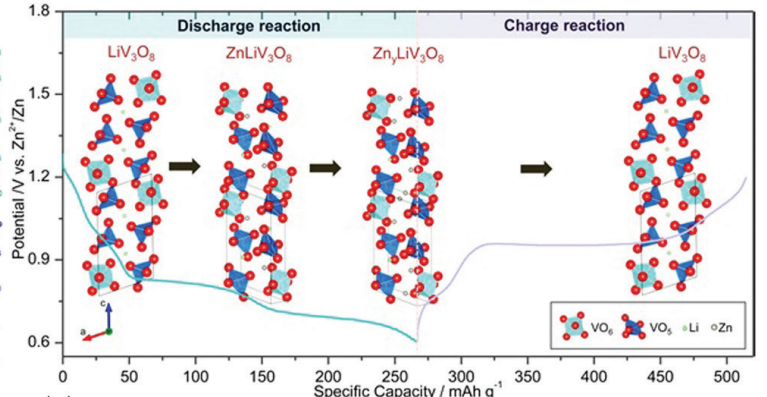

(c)



Fig. 9. Schematic and evidence of electrochemical reaction mechanism of $\mathrm{V}_{3} \mathrm{O}_{8}$ cathode in Zinc ion battery (a) $\mathrm{LiV}_{3} \mathrm{O}_{8}{ }^{39}$, (b) $\mathrm{H}_{2} \mathrm{~V}_{3} \mathrm{O}_{8}{ }^{40)}$, (c) $\mathrm{Na}_{2} \mathrm{~V}_{6} \mathrm{O}_{16} \cdot 1.63 \mathrm{H}_{2} \mathrm{O}^{41}$

의해 구조적 안정성이 향상됨을 확인하였다. (Fig. 9.)

최근 Linda F. Nazar 그룹에서는 $\mathrm{V}_{3} \mathrm{O}_{8}$ 층상 구조와 유사한 $\mathrm{V}_{3} \mathrm{O}_{7} \cdot \mathrm{H}_{2} \mathrm{O}$ 를 아연 이온 이차전지의 양극소재로 적용한 연구결과를 발표하였다. ${ }^{42)}$ 전기화학 특성평가결 과 $1 \mathrm{C}$ 의 전류밀도 조건에서 $375 \mathrm{mAh} \mathrm{g}^{-1}$ 의 용량 특성과 $8 \mathrm{C}$ 의 높은 전류밀도 조건에서 $275 \mathrm{mAh} \mathrm{g}^{-1}$ 의 용량 특성 을 발현하여 우수한 에너지 밀도 및 출력밀도를 증명하였 다. 이 소재의 전기화학 반응 메커니즘을 분석하기 위해 In-situ X-ray Diffraction(XRD)분석을 진행하였으 며, $\mathrm{V}_{3} \mathrm{O}_{8}$ 과는 달리 충 - 방전 과정에서 새로운 상인 $\mathrm{Zn}_{4}(\mathrm{OH})_{6} \mathrm{SO}_{4} \cdot 5 \mathrm{H}_{2} \mathrm{O}$ (Zinc hydroxide sulfate)이 형 성/분해됨을 확인하였다. 이 메커니즘은 새롭게 보고된 것은 아니지만 이 반응에 대한 정확한 메커니즘이 규명되 지 않았었다. ${ }^{19)}$ 이 그룹에서는 전해질로부터 발생한 용존 산소가 반응 가능한 화학 종 $\left(\mathrm{Zn}^{2+}, \mathrm{SO}_{4}{ }^{2-}\right.$ 및 $\left.\mathrm{H}_{2} \mathrm{O}\right)$ 과 반응 하는 부작용에 의하여 전극의 표면에 형성된 결과라고 주 장하고 있다. 이에 대한 산화환원 반응 및 동역학과 관련 하여 실제 메커니즘을 규명하기위해서는 추가적인 분석 이 필요한 실정이다.

Jaekook Kim 그룹에서는 $\mathrm{V}_{3} \mathrm{O}_{8}$ 층상구조를 기반으로
새로운 pryo vanadate 구조의 $\alpha-\mathrm{Zn}_{2} \mathrm{~V}_{2} \mathrm{O}_{7}$ 를 아연 이온 이차전지의 양극소재로 적용한 연구결과를 발표하였 다. ${ }^{43)}$ 이 pyro vanadate 구조는 $\mathrm{VO}_{4}$ 사면체와 $\mathrm{ZnO}_{5}$ bipyramid 삼방정계로 구성된 층상구조로 이루어져 있 으며 구조적 특징으로 안정성을 향상시킬 수 있다. 이에 대한 전기화학 특성평가 결과, 아연이온의 삽리 메커니즘 을 통해 $300 \mathrm{~mA} \mathrm{~g}^{-1}$ 의 전류밀도 조건에서 200 회 충 · 방 전 이후 $197 \mathrm{mAh} \mathrm{g}^{-1}$ 의 용량특성과 $4,000 \mathrm{~mA} \mathrm{~g}^{-1}$ 의 매우 높은 전류밀도 조건에서 1,000 회 충 · 방전 이후 $138 \mathrm{mAh}$ $\mathrm{g}^{-1}$ 의 용량특성을 발현함을 확인하였다. 이를 통해 pyro vanadate 구조의 구조적 안정성에 따른 우수한 수명 특 성 및 고율 특성을 규명하였다.

Husam N. Alshareef 그룹에서는 또 다른 pyro vanadate 구조인 $\mathrm{Zn}_{3} \mathrm{~V}_{2} \mathrm{O}_{7}(\mathrm{OH})_{2} \cdot 2 \mathrm{H}_{2} \mathrm{O}$ 를 아연 이온 이차전지의 양극소재로 적용한 연구결과를 발표하였 다. ${ }^{44)} 1 \mathrm{M} \mathrm{ZnSO}_{4}$ 전해질을 활용하여 전지를 구성하였으 며 0.2 1.8V의 전압범위에서 전기화학 특성평가를 진행 하였다. 그 결과, 300 회의 충 · 방전 이후에도 $101 \mathrm{mAh}$ $\mathrm{g}^{-1}$ 의 용량특성을 발현하여 우수한 수명특성을 갖는 소재 임을 규명하였다. 
(a)

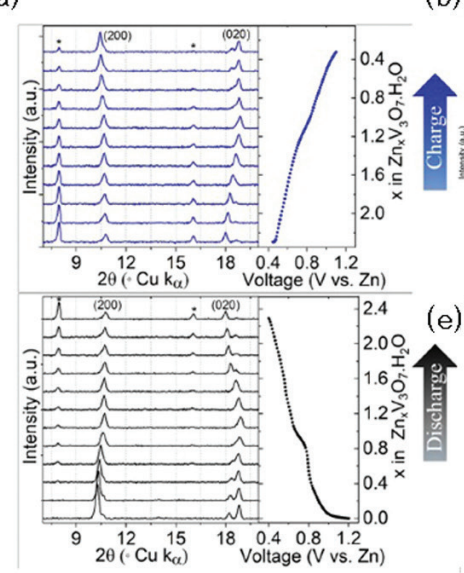

(b)

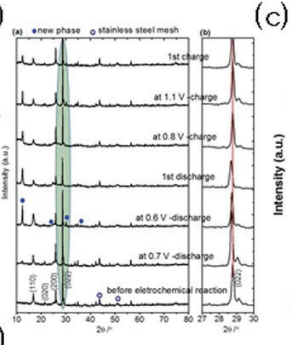

(c)

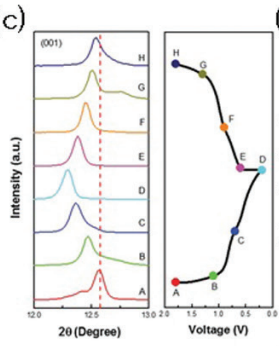

(d)

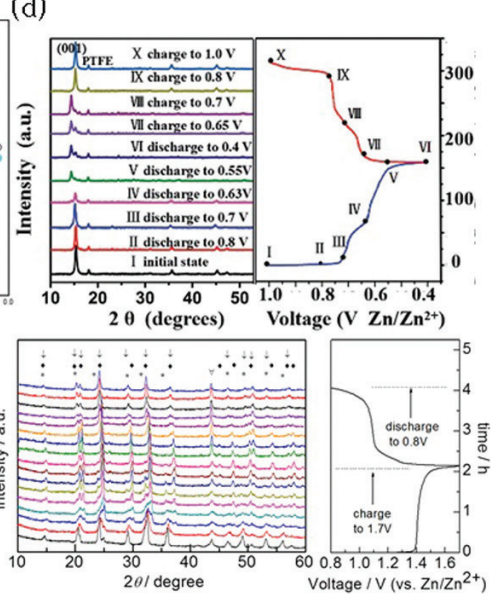

Fig. 10. Schematic and evidence of electrochemical reaction mechanism of other vanadium-based cathode in Zinc ion battery $(a) \mathrm{V}_{3} \mathrm{O}_{7}^{42}$, (b) pyro-vanadate $\mathrm{Zn}_{2} \mathrm{~V}_{2} \mathrm{O}_{7}{ }^{43}$ ), (c) pyro-vanadate $\mathrm{Zn}_{3} \mathrm{~V}_{2} \mathrm{O}_{7}{ }^{44)}$, (d) $\mathrm{VS}_{2}{ }^{45)}$, (e) $\mathrm{Na}_{3} \mathrm{~V}_{2}\left(\mathrm{PO}_{4}\right)_{3}{ }^{46)}$

Liqiang Mai 그룹에서는 흑연 라멜라(graphite lamellar)와 유사한 층상구조를 가지며 $6.76 \AA$ 의 층간 간 격을 갖는 육방정계 구조의 전이금속 디칼로겐 화합물 (Transition-metal dichalcogenides)인 $\mathrm{VS}_{2}$ 를 아연 이 온 이차전지의 양극소재로 적용한 연구결과를 발표하였 다. ${ }^{45)}$ 이 연구결과는 아연 이온 이차전지에 대한 최초의 칼로겐 화합물을 적용한 연구결과로 200회의 충 - 방전 이후에도 초기 방전 용량대비 $98 \%$ 에 해당하는 $110 \mathrm{mAh}$ $\mathrm{g}^{-1}$ 의 용량특성을 발현함을 확인하였다. 이 소재의 전기 화학 반응 메커니즘을 규명하기 위해 순환전압주사법 (Cyclic Voltammetry)을 진행하였으며, 총 용량의 $62 \%$ 에 해당하는 용량이 $0.2 \mathrm{mV} \mathrm{S}^{-1}$ 의 정 전압 밀도에서 capacitive/pseudo capacitive 반응에 의해 발현됨을 확 인하였다. 이를 통해 $\mathrm{VS}_{2}$ 소재는 아연 이온의 삽입에 따 른 conversion 반응과 커패시터 반응(capacitive/ pseudo capacitive) 두 가지의 반응에 기초하여 전기화 학 반응이 발생함을 확인하였다.

Yunhui Huang 그룹에서는 NASICON구조의 바나듐 인산염계 소재인 $\mathrm{Na}_{3} \mathrm{~V}_{2}\left(\mathrm{PO}_{4}\right)_{3}$ 를 아연 이온 이차전지의 양극소재로 적용한 연구결과를 발표하였다. ${ }^{46)} 0.5 \mathrm{M} \mathrm{Zn}$ $\left(\mathrm{CH}_{3} \mathrm{COOH}\right)_{2}$ 전해질을 활용하여 전지를 구성하였으며, 전기화학 특성평가 결과 $0.5 \mathrm{C}$ 의 전류밀도 조건에서 $97 \mathrm{mAh} \mathrm{g}^{-1}$ 의 초기 용량 특성을 발현함을 확인하였으며
100 회의 충 · 방전 이후 초기방전 용량 대비 $74 \%$ 가 유지 되는 특성을 확인하였다. 이러한 전기화학 반응의 메커니 즘을 분석한 결과, $\mathrm{Na}_{3} \mathrm{~V}_{2}\left(\mathrm{PO}_{4}\right)_{3}$ 에 자리하고 있던 2 개의 소듐 이온이 첫 충전 반응 시에 전기화학적으로 탈리되고 이후 방전 반응에서 아연 이온이 그 자리에 삽리 됨에 따 라 새로운 $\mathrm{Zn}_{\mathrm{x}} \mathrm{NaV}_{2}\left(\mathrm{PO}_{4}\right)_{3}$ 상이 형성됨을 확인하였다. (Fig. 10.)

\subsection{3 개방형 구조체(Open Framework Structures)양극 소재}

최근 다가 양이온의 삽.탈 리가 가능한 소재로 Prussian Blue Analogous(PBAs)와 같은 개방형 구조 체에 대한 관심이 증가되면서 이를 아연 이온 이차전지의 양극소재로 적용하는 연구사례들도 보고되고 있다. Zhaoping Liu 그룹에서는 $3 \mathrm{D}$ 구조의 $\mathrm{Zn}_{3}\left[\mathrm{Fe}(\mathrm{CN})_{6}\right]_{2}$ $(\mathrm{ZnHCF})$ 소재를 아연 이온 이차전지의 양극소재로 적용 한 결과를 발표하였다. ${ }^{47,48)}$ 0.8 2.0V의 전압범위 조건 에서 전기화학 특성을 평가한 결과, $60 \mathrm{~mA} \mathrm{~g}^{-1}$ 의 전류밀 도 조건에서 100 회의 충 · 방전 이후에도 초기 방전용량 대비 $76 \%$ 의 용량특성을 발현하였다. 추가적으로 $300 \mathrm{~mA}$ $\mathrm{g}^{-1}$ 의 높은 전류밀도 조건에서는 100 회의 충 · 방전 이후 에도 초기 방전용량 대비 $81 \%$ 의 용량특성을 발현함을 확 인하였다. 이와 같은 결과는 $\mathrm{Zn}_{3}\left[\mathrm{Fe}(\mathrm{CN})_{6}\right]_{2}(\mathrm{ZnHCF})$ 소 재가 전기화학 반응에서 전류밀도에 영향을 받지 않는 것 
을 보여주며 전지 내부의 산소에 대한 저항력이 있음을 보여주고 있다. 이 전지의 전기화학 반응 메커니즘을 규 명하기 위해 순환전압주사법(Cyclic Voltammetry)을 활용하였으며 아연 이온의 삽 - 탈리에 따른 산화 - 환원 피크가 각각 $1.75 \mathrm{~V} / 1.66 \mathrm{~V}$ 에서 나타나고 평균 작동전압 이 $1.7 \mathrm{~V}$ 임을 확인하였다. ${ }^{47)} 3 \mathrm{M} \mathrm{ZnSO}_{4}$ 전해질 조건에서 전기화학 특성평가를 진행한 결과, 작동전압이 보다 향상 된 $1.73 \mathrm{~V}$ 임을 확인하였으며, $300 \mathrm{~mA} \mathrm{~g}^{-1}$ 의 높은 전류밀 도 조건에서 200 회의 충 - 방전 이후 초기방전용량 대비 $80 \%$ 의 용량특성을 발현함을 확인하였다. ${ }^{48)}$

Fabio La Manita 그룹에서는 개방형 구조의 $\mathrm{KCu}$ $\left[\mathrm{Fe}(\mathrm{CN})_{6}\right](\mathrm{CuHCF})$ 소재를 아연 이온 이차전지의 양극소 재로 적용한 결과를 발표하였다. ${ }^{49)}$ 전기화학 특성평가 결 과, $1.73 \mathrm{~V}$ 의 평균 작동전압을 보이며 $1 \mathrm{C}$ 의 전류밀도 조건 에서 100 회 충 - 방전 이후 초기방전 용량 대비 $96 \%$ 의 용 량이 유지됨을 확인하였다. 일반적으로 아연 금속을 음극 으로 활용하는 아연 이온 이차전지는 반복되는 충 - 방전 을 통해 금속 표면에 dendrite가 형성되며 이에 따른 수 소가스 발생이 동반되어 수명특성이 급격하게 저하된다.
이 전지에서는 약산성 및 저 농도의 $\left(\mathrm{pH}\right.$ 6) $\mathrm{ZnSO}_{4}$ 전해질 을 활용하여 아연에 대한 pourbaix 다이어그램과 일치하 게 만들어 아연 금속의 전기화학 반응을 억제하는 $\mathrm{ZnO}$ 와 $\mathrm{Zn}(\mathrm{OH})_{2}$ 와 같은 부산물 형성을 막는 것을 확인하였다.

추가적으로 $\mathrm{Yi}$ Wang 그룹에서는 $\mathrm{KCu}\left[\mathrm{Fe}(\mathrm{CN})_{6}\right]$ $(\mathrm{CuHCF})$ 소재를 앞선 그룹과 다른 전해질 조건인 $1 \mathrm{M}$ $\mathrm{ZnSO}_{4}$ 전해질을 활용한 아연 이온 이차전지에 적용한 연 구결과를 발표하였다. ${ }^{50)}$ 이 전지의 전기화학 특성평가 결 과, $20 \mathrm{~mA} \mathrm{~g}^{-1}$ 의 전류밀도 조건에서 초기 $56 \mathrm{mAh} \mathrm{g}^{-1}$ 의 방 전용량 특성을 발현하였으며 20 회 충 · 방전 이후 $43 \mathrm{mAh}$ $\mathrm{g}^{-1}$ 의 방전용량 특성을 발현함을 확인하였다. 이 전기화학 반응을 통해 아연 이온의 삽 - 탈리는 개방형 구조에 영향 을 주지 않고 결정 내 격자 간격을 통해 확산함에 따른 고 체상 확산 동역학을 통한 메커니즘임을 확인하였다.

Fabio La Manito 그룹에서는 $\mathrm{KCu}\left[\mathrm{Fe}(\mathrm{CN})_{6}\right]$ $(\mathrm{CuHCF})$ 소재가 적용된 아연 이온 이차전지의 전해질 종류 및 전해질 농도, 전류 밀도 등에 대한 연구결과를 추 가로 발표하였다. ${ }^{51)}$ 전해질 염의 종류로는 $\mathrm{ZnSO}_{4}, \mathrm{ZnF}_{2}$, $\mathrm{Zn}\left(\mathrm{ClO}_{4}\right)_{2}$ 및 $\mathrm{Zn}\left(\mathrm{NO}_{3}\right)_{2}$ 을 활용하였으며 각 전해질 별 다

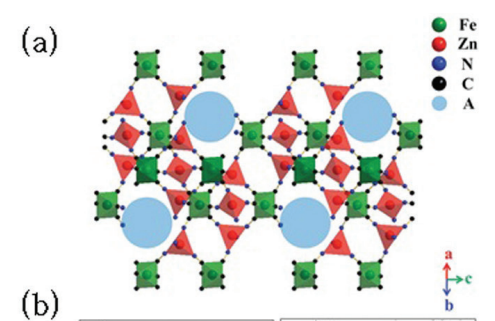

(c)

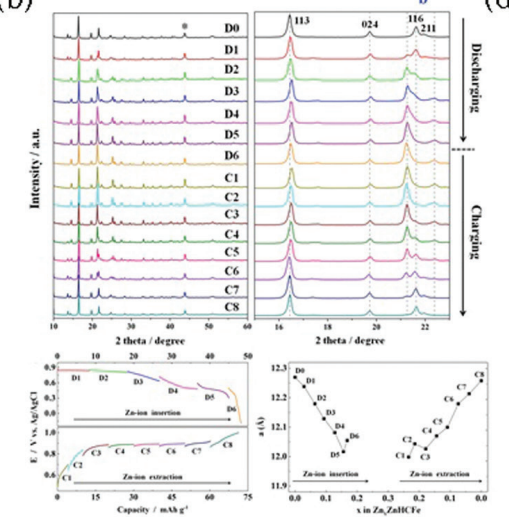

(d)


Fig. 11. Schematic and evidence of electrochemical reaction mechanism of open framework structure cathode in Zinc ion battery (a), (b) $\mathrm{Zn}_{3}\left[\mathrm{Fe}(\mathrm{CN})_{6}\right]_{2}^{47.48)}$, (c), (d) $\mathrm{KCu}\left[\mathrm{Fe}(\mathrm{CN})_{6}\right]^{79-51)}$ 
른 농도를 활용하여 평가한 결과, 전해질 내 아연이온의 농도뿐만 아니라 염을 구성하는 음이온이 전기화학 반응 의 안정성을 향상시킨다는 결론이 도출되었다. 그 중, $\mathrm{ZnSO}_{4}$ 전해질을 활용한 전지를 통해 $\mathrm{CuHCF}$ 의 충 - 방 전에 따른 퇴화 메커니즘을 규명하였다. 그 결과 초기 $\mathrm{CuHCF}$ 로의 아연 이온 삽입은 단일 상 반응으로 나타났 지만 평형 단계를 지난 후 부분적으로 $\mathrm{ZnHCF}$ 로 상 변화 가 발생함을 확인하였으며 이후 단계부터는 완벽한 2 상 반응으로 나타남을 확인하였다. 이러한 상 변화는 $1 \mathrm{C}$ 의 전류밀도 조건에서는 250회의 충 · 방전 이후 완벽하게 관측이 되었으나 $10 \mathrm{C}$ 의 높은 전류밀도 조건에서는 800 회의 충 - 방전 이후에도 약하게 발견되었다. 이를 통해 $\mathrm{CuHCF}$ 의 퇴화 반응은 전류 밀도에 영향을 받음을 확인 하였으며 이러한 퇴화 메커니즘은 향후 안정되고 긴 수명 특성을 갖는 전지를 개발하는데 도움이 될 것이라 예상된 다. (Fig. 11.)

\section{2 음극소재}

\subsection{1아연 금속}

아연 금속은 수계 전해질에서 가역적인 산화 - 환원 반 응을 나타내며 높은 이론용량 $\left(\sim 820 \mathrm{mAh} \mathrm{g}^{-1}\right)$ 을 발현한 다. 또한 다른 전하수송체를 제공하는 금속 $(\mathrm{Li}, \mathrm{Na}$ 및 $\mathrm{K})$ 과 달리 낮은 산화 · 환원 전위 $(-0.76 \mathrm{~V}$ vs. SHE)를 가지 고 있어 과전압에서 발생하는 전해질 분해에 의한 수소가 스 발생을 억제할 수 있다. 이러한 특성으로 아연 금속은 초기 개발된 아연 알칼리 전지, 아연-공기 전지, 아연니켈 전지 및 아연 이온 이차전지와 같이 에너지저장 및

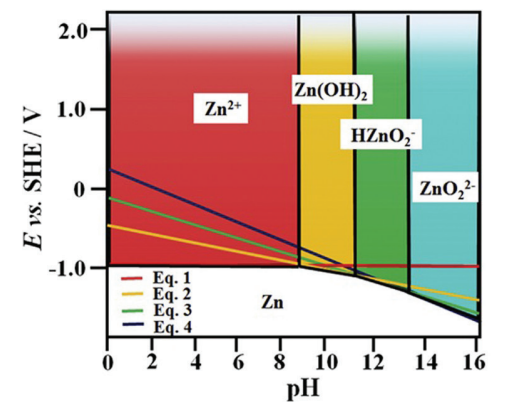

변환장치 애플리케이션에 가장 널리 사용되는 음극 재료 중 하나이다. ${ }^{8,35)}$ 하지만 초기 개발되었던 알칼리성 $\mathrm{KOH}$ 전해질로 구성된 $\mathrm{Zn}-\mathrm{MnO}_{2}$ 전지에서 아연 금속의 반응 은 pourbaix 다이어그램에서 나타나는 것과 같이 $\mathrm{Zn}(\mathrm{OH})_{2}, \mathrm{HZnO}_{2}{ }^{-}$등이 충 - 방전 과정에서 형성된다. (Fig. 12.) 이는 전해질의 용매인 물의 분해반응을 일으켜 수소가스를 발생시키며 이러한 현상은 전지의 안정성을 저하시키는 요소로 작용하여 전지의 단락현상과 폭발을 야기한다. ${ }^{52)}$ 또한, 아연 금속의 충 - 방전 과정에서 형성 되는 dendrite는 아연 이온의 가역적인 증착을 방해하여 전지의 성능을 저하시킨다. 이와 같은 반응은 아연-니켈 전지에서 가장 많이 발생하며 이는 $\mathrm{Zn} \rightleftarrows \mathrm{Zn}(\mathrm{OH})_{4}{ }^{2-}$ 의 산화 - 환원 반응이 dendrite 형성조건에 유리하기 때문 이다. ${ }^{53)}$

위와 같은 이유로 최근 연구되고 있는 아연 이온 이차 전지는 산성 및 약 산성조건의 전해질을 활용하고 있으 며, 이 조건에서는 부산물이 형성되지 않아 안정적인 전 기화학 반응을 발현할 수 있다. 특히 $\mathrm{Zn} \rightleftarrows \mathrm{Zn}^{2+}$ 의 산 화 · 환원 반응에 기초한 전기화학 반응으로 dendrite는 거의 형성되지 않는다. 하지만 산성 전해질 조건에서도 발생하는 아연 금속 표면 증착 효율 문제로 이를 향상시 키기 위한 연구가 요구되고 있다.

이에 알칼리 전해질 조건에서 증착 효율을 향상시키기 위해 다음과 같은 많은 연구가 진행되었다. 아연 전극에 첨가제( $\mathrm{Ca}, \mathrm{In}, \mathrm{Bi}, \mathrm{Ti}, \mathrm{Nd}, \mathrm{Ag}$ 산화물 또는 수산화물)를 혼합하거나 아연을 다른 금속과 합금화를 통해 구조 및 형상을 제어하여 전기화학적 성능을 향상을 시도하였 다. ${ }^{54,55)}$ 또한 최근 Debra R. Rolison 그룹의 연구결과,

\section{Zinc Redox reaction in Alkali solution}

- $\mathrm{pH} \approx 8 \sim 10$

$: \mathrm{Zn}^{2+}+2 \mathrm{H}_{2} \mathrm{O} \approx \mathrm{Zn}(\mathrm{OH})_{2}+2 \mathrm{H}^{+}$

- $\mathrm{pH} \approx 10 \sim 12$

$: \mathrm{Zn}(\mathrm{OH})_{2} \gtrless \mathrm{HZnO}_{2}^{-}+\mathrm{H}^{+}$

- $\mathrm{pH} \approx 13$

$: \mathrm{HZnO}_{2}^{-} \gtrless \mathrm{ZnO}_{2}^{2-}+\mathrm{H}^{+}$

Fig. 12. Pourbaix diagram for zinc in different $\mathrm{pH}$ in water (low zinc ion concentration $\approx 10^{-6} \mathrm{M}$ ) 
(a)

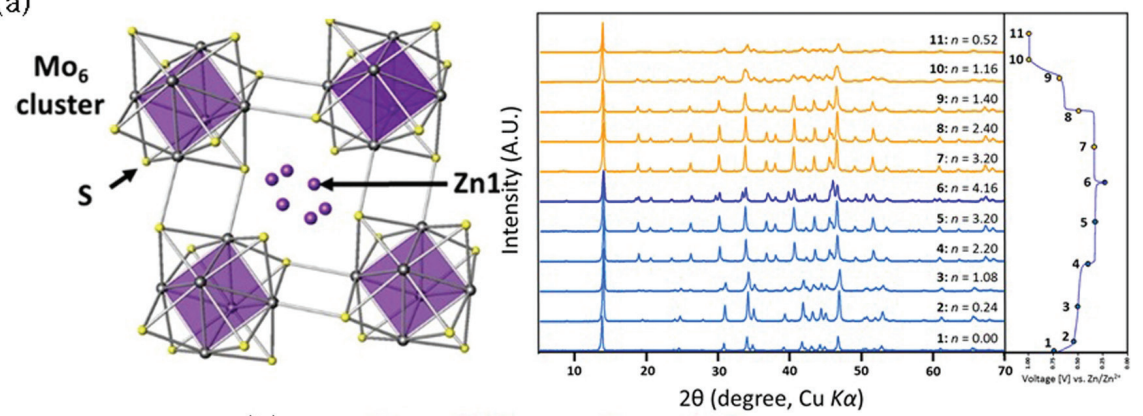

(b)

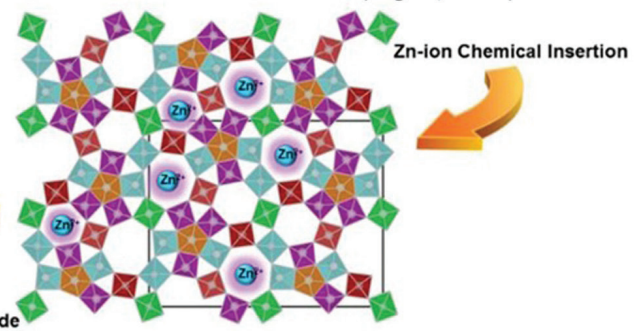

Fig. 13. Schematic and evidence of electrochemical reaction mechanism of crystal structure-based anode in Zinc ion battery (a) $\mathrm{Mo}_{6} \mathrm{~S}_{8}^{58)}$, (b) $\mathrm{Zn}_{x} \mathrm{MO}_{2.5+\mathrm{y}} \mathrm{VO}_{9+2}{ }^{59)}$

$\mathrm{In}$ 과 $\mathrm{Bi}$ 이 도핑된 스펀지 형태의 $\mathrm{BD}$ 아연 전극이 전기 화 학적 성능을 향상시킬 수 있음을 밝혔다. ${ }^{56)}$ 이 방법들은 알칼리 전해질 조건에서 개발되었지만, 산성 또는 중성 전해질 조건에도 적용 가능하다. 산성 전해질 조건에서 아연 이온의 증착 효율을 향상시키기 위해 Feiyu Kang 그룹에서는 금속 아연 입자와 활성 카본을 혼합하여 제조 한 복합체를 아연 이온 이차전지의 음극으로 적용하였 다. ${ }^{57)}$ 그 결과, 80 회 충 - 방전 이후 활성 카본이 혼합되 지 않은 순수 전극보다 $56.7 \%$ 높은 특성을 발현함을 확 인하였으며 이를 통해 아연이온의 증착 효율이 향상됨을 확인하였다.

\subsection{2 결정계 음극 소재}

앞선 장에서 소개한 아연 금속의 경우 아연 이온 이차 전지의 안정성을 저하시키는 문제가 있어 새로운 음극소 재에 대한 연구가 필요하다. 이에 Seung Tae Hong 그 룹에서는 Chevrel 구조의 $\mathrm{Mo}_{6} \mathrm{~S}_{8}$ 소재를 아연 이온 이차 전지의 음극소재로 적용한 연구결과를 발표하였다. ${ }^{58)}$ 전 기화학 특성평가를 위해서 $\mathrm{ZnSO}_{4}$ 전해질을 활용하여 전 지를 구성하였으며, $0.05 \mathrm{C}$ 의 전류밀도 조건에서 $134 \mathrm{mAh}$ $\mathrm{g}^{-1}$ 의 용량특성을 발현, 20 회의 충 · 방전 이후 우수한 용 량 유지 특성을 발현하는 것을 확인하였다. 이에 대한 전 기화학 반응 메커니즘을 분석한 결과, 방전반응동안 구조 내 변화하는 아연 이온의 몰 비에 따라 단일 상 $\left(\mathrm{Mo}_{6} \mathrm{~S}_{8} \sim \mathrm{Zn}_{0,24} \mathrm{Mo}_{6} \mathrm{~S}_{8}\right)$ 과 2상 $\left(\mathrm{Zn}_{0,24} \mathrm{Mo}_{6} \mathrm{~S}_{8} \sim \mathrm{Zn}_{2,2} \mathrm{Mo}_{6} \mathrm{~S}_{8}\right)$ 반응이 각각 나타남을 확인하였다. (Fig. 13.)

Arumugam Manthiram 그룹에서는 개방형 터널 구 조를 갖는 $\mathrm{Zn}_{\mathrm{x}} \mathrm{Mo}_{2,5+\mathrm{y}} \mathrm{VO}_{9+z}$ 소재를 아연 이온 이차전지 의 음극소재로 적용한 연구결과를 발표하였다. ${ }^{59)}$ 전기화 학 특성평가를 위해서 $0.5 \mathrm{M} \mathrm{Zn}\left(\mathrm{CH}_{3} \mathrm{COO}\right)_{2}$ 전해질을 활 용하여 전지를 구성하였으며, $20 \mathrm{~mA} \mathrm{~g}^{-1}$ 의 전류밀도 조 건에서 $180 \mathrm{mAh} \mathrm{g}^{-1}$ 의 용량특성을 발현하는 것을 확인하 였다. 또한 아연 이온의 반복된 삽 - 탈리 동안 안정된 구 조적 특성을 발현하여 우수한 안정성을 갖는 소재임을 확 인하였다.

\section{3. 결론}

아연 이온 이차전지는 2012년 Feiyu Kang 그룹의 연 구결과 발표 이후, 새로이 관심을 얻고 이후 많은 연구들 
(a)

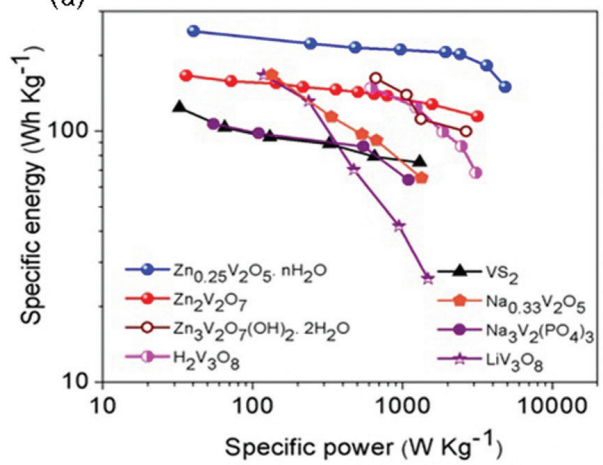

(b)

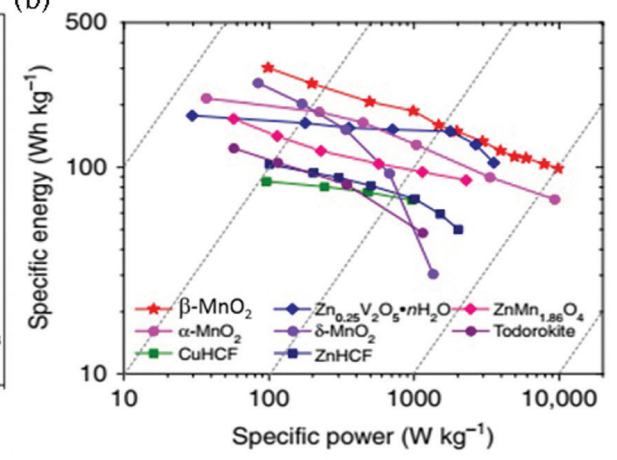

Fig. 14. Ragone plots for few selected (a) vanadium-based cathodes and (b) manganese and open framework structures-based electrodes

을 통해 발전하였다. 특히, 전지의 에너지 밀도 및 출력 밀도를 결정하는 양극소재에 관한 연구는 초기 망간계 산 화물에서 바나듐계 산화물 그리고 개방형 구조체에 이르 기까지 다양한 연구들이 불과 10 년이 채 되지 않는 기간 에 진행되었으며, 대부분 높은 전류밀도 조건에서 우수한 전기화학 특성들을 발현하였다. 이와 같이 우수한 전기화 학 특성을 기반으로 하는 아연 이온 이차전지 양극소재의 중 - 대형 전지 적용 가능성을 Ragone plot을 활용하여 비교하였다. 23) (Fig. 14.)

먼저 바나듐계 양극소재별 전기화학 특성을 비교한 결 과, $\mathrm{Zn}_{0.25} \mathrm{~V}_{2} \mathrm{O}_{5}$ 전극은 40 및 $4860 \mathrm{~W} \mathrm{~kg}$ 의 출력밀도에 서 각각 $250 \mathrm{Wh} \mathrm{kg}^{-1}$ 및 $150 \mathrm{Wh} \mathrm{kg}^{-1}$ 의 에너지 밀도 특 성을 발현함을 확인하였다. ${ }^{35)}$ 다음으로 나노 와이어 형태 의 $\mathrm{Zn}_{2} \mathrm{~V}_{2} \mathrm{O}_{7}$ 전극은 36.3 및 $114.3 \mathrm{~W} \mathrm{~kg}$ 의 출력밀도에 서 각각 $166.3 \mathrm{Wh} \mathrm{kg}^{-1}$ 및 $114.3 \mathrm{Wh} \mathrm{kg}$ 의 에너지 밀도 특성을 발현함을 확인하였다. ${ }^{43)}$

다음으로 망간계 양극소재별 전기화학 특성을 비교한 결과, 나노 막대형태의 $\beta-\mathrm{MnO}_{2}$ 전극은 197 및 $5910 \mathrm{~W}$ $\mathrm{kg}^{-1}$ 의 출력밀도에서 각각 $254 \mathrm{Wh} \mathrm{kg}^{-1}$ 및 $110 \mathrm{Wh} \mathrm{kg}$ 의 에너지 밀도 특성을 발현함을 확인하였다. 흥미롭게도 이 전극을 활용한 이차전지는 $1520 \mathrm{mAh}$ 의 높은 가역 용 량과 $75.2 \mathrm{Wh} \mathrm{kg}^{-1}$ 총 에너지 밀도를 발현하여, 지금까 지 수계 아연 이온 이차전지 기술에서 달성 된 최고 수치 를 보여주고 있다.

앞서 설명한 바나듐계 및 망간계 양극소재를 활용한 전
극 모두 상용화 된 $\mathrm{Pb}-\mathrm{acid}\left(30 \mathrm{Wh} \mathrm{kg}^{-1}\right.$ )와 $\mathrm{Ni}-\mathrm{Cd}$ $\left(50 \mathrm{Wh} \mathrm{kg}^{-1}\right)$ 전지보다 높은 에너지 밀도 특성을 보였으 며 이를 통해 중 - 대형 전력저장 시스템의 적용가능성을 확인할 수 있다. 이와 같이 아연 이온 이차전지는 고성능, 높은 가격 경쟁력, 친환경적, 고 안정성을 기반으로 전지 의 특성을 향상시켜 대용량 에너지 저장장치로의 활용가 능성이 주목받고 있다.

하지만 지금까지 연구된 아연 이온 이차전지는 물을 전 해질로 활용하는 전지로 내부에서 망간과 바나듐을 기반 으로 하는 양극소재들의 구조적 안정성 문제로 인해 낮은 전류밀도 조건에서 관측 가능한 정확한 전기화학 반응 메 커니즘을 확인하기 어렵다. 또한 (1) 음극으로 활용하는 아연금속의 표면에 형성되는 dendrite와 이에 따른 수소 가스 발생 억제, (2) 전기화학 반응 과정에서 발생하는 $\mathrm{Zn}$-hydroxidesulfate의 형성 메커니즘 및 역할 규명, (3) 전기화학 반응 중에 발생하는 퇴화에 대한 확실한 메 커니즘 규명, (4) 에너지 밀도 향상을 위한 작동전압 향상 등 아직까지 해결해야할 문제가 남아있다.

본 저자는 이 리뷰를 통해 향후 아연 이온 이차전지의 성능 향상을 위해 앞선 문제들에 대한 연구의 필요성을 언급하고자 하였다. 추가적으로 (1) 구조적으로 안정한 인산염 또는 비정질 구조의 유 - 무기 하이브리드 재료를 기반으로 하는 새로운 나노 소재에 대한 연구, (2) 정확한 전기화학 반응 메커니즘 규명을 위한 이론적 모델링과 결 합된 이론/전산 연구, (3) 에너지 밀도 향상을 위한 유기 
전해질 활용 전지시스템 도입 및 다중 이온 삽 - 탈리 기 반의 하이브리드 전지 연구 등 이와 같은 새로운 전략을 통해 아연 이온 이차전지가 차세대 전력 저장 장치로 널 리 활용되어 현대사회에서 추구하는 친환경적이고 지속 가능한 에너지에 대한 요구에 부응할 것으로 전망한다.

\section{참고문헌}

1. V. Etacheri, R. Marom, R. Elazari, G. Salitra, D. Aurbach, "Challenges in the development of advanced Li-ion batteries: A review" Energy Environ. Sci., 4, 3243-3262 (2011)

2. J.W. Fergus, "Developments in cathode materials for lithium ion batteries" J. Power Sources, 195, 939-954 (2010)

3. B. Dunn, H. Kamath, J.M. Tarascon, "Electrical energy storage for the grid: A battery of choices" Science, 334, 928-93 5(2011)

4. Q. Wang, P. Ping, X. Zhao, G. Chu, J. Sun, C. Chen "Thermal runaway caused fire and explosion of lithium ion battery" J. Power Sources, 208, 210-224 (2012)

5. J. Wen, Y. Yu, C. Chen, "A review on lithium-ion batteries safety issues: Existing problems and possible solutions" Mater. Express, 2, 197-212 (2012)

6. R.Y. Wang, C.D. Wessells, R.A. Huggins, Y. Cui, "Highly reversible open framework nanoscale electrodes for divalent ion batteries" Nano Lett., 13, 5748-5752 (2013)

7. S. Liu, G.L. Pan, G. Li., X.P. Gao, "Copper hexacyanoferrate nanoparticles as cathode material for aqueous Al-ion batteries" J. Mater. Chem. A, 3, 959-962 (2015)

8. C. Xu, B. Li, H. Du, F. Kang, "Energetic zinc ion chemistry: The rechargeable zinc ion battery" Angew. Chem. Int. Ed., 51, 933-935 (2012)

9. A.R. Mainar, E. Iruin, L.C. Colmenares, A. Kvasha, I. Meatza, M. Bengoechea, O. Leonet, I. Boyano, C. Zhang, J.A. Blazquez, "An overview of progress in electrolytes for secondary zinc-air batteries and other storage systems based on zinc" J. Energy Storage, 15, 304-328 (2018)

10. K. Kordesch, P.A. Marsal, L.F. Urry, "Dry cell" US Patent 2960558A (1957)

11. W.C. Vosburgh, "The manganese dioxide electrode" $J$, Electrochem, Soc., 106, 839-845 (1959)
12. A. Kozawa, J.F. Yeager, "The cathodic reduction mechanism of electrolytic manganese dioxide in alkaline electrolyte” J. Electrochem. Soc., 112, 959963 (1965)

13. K.J. Vetter, "A general thermodynamic theory of the potential of passive electrodes and its influence on passive corrosion” J. Electrochem. Soc., 110, 597-605 (1963)

14. S. Deravaj, N. Munichandraiah, "Effect of crystallographic structure of $\mathrm{MnO}_{2}$ on its electrochemical capacitance properties" J. Phys. Chem. C, 112, 4406-4417 (2008)

15. C. Xu, Y. Chen, S. Shi, J. Li, F. Kang, D. Su, "Secondary batteries with multivalent ions for energy storage" Sci. Rep., 5, 14120-14128 (2015)

16. M.H. Alfaruqi, J.H. Gim, S.J. Kim, J.J. Song, J.G. Jo, S.H. Kim, V. Mathew, J. Kim, "Enhanced reversible divalent zinc storage in a structurally stable $\alpha-\mathrm{MnO}_{2}$ nanorod electrode” J. Power Sources, 288, 320-327 (2015)

17. B.E. Lee, H.R. Lee, H.S. Kim, K.Y. Chung, B.W. Cho, S.H. Oh, "Elucidating the intercalation mechanism of zinc ions into $\alpha-\mathrm{MnO}_{2}$ for rechargeable zinc batteries" Chem. Commun., 51, 9265-9268 (2015)

18. B.E. Lee, C.S. Yoon, H.R. Lee, K.Y. Chung, B.W. Cho, S.H. Oh, "Electro chemically-induced reversible transition from the tunneled to layered polymorphs of manganese dioxide" Sci. Rep., 4, 6066 (2014)

19. B.E. Lee, H.R. Seo, H.R. Lee, C.S. Yoon, J.H. Kim, K.Y. Chung, B.W. Cho, S.H. Oh, "Critical role of $\mathrm{pH}$ evolution of electrolyte in the reaction mechanism for rechargeable zinc batteries" ChemSusChem, 9, 1-10 (2016)

20. H. Pan, Y. Shao, P. Yan, Y. Cheng, K.S. Han, Z. Nie, C.M. Wang, J. Yang, X. Li, P. Bhattacharya, K.T. Mueller, J. Liu, "Reversible aqueous zinc/manganese oxide energy storage from conversion reactions" $N a t$. Energy, 1, 16039 (2016)

21. M.H. Alfaruqi, V. Mathew, J.H. Gim, S.J. Kim, J.J. Song, J.P. Baboo, S.H. Choi, J. Kim, "Electrochemically induced structural transformation in a $\gamma-\mathrm{MnO}_{2}$ cathode of a high capacity zinc-ion battery system" Chem. Mater., 27, 3609-3620 (2015)

22. M.H. Alfaruqi, J.H. Gim, S.J. Kim, J.J. Song, D.T. Pham, J.G. Jo, Z. Xiu, V. Mathew, J. Kim, "A layered $\delta-\mathrm{MnO}_{2}$ nanoflake cathode with high zinc-storage capacities for eco-friendly battery applications" Electrochem. Commun., 60, 121-125 (2015) 
23. N. Zhang, F. Cheng, J. Liu, L. Wang, X. Long, X. Liu, F. Li, J. Chen, "Rechargeable aqueous zincmanganese dioxide batteries with high energy and power densities" Nat. Commun., 8, 405 (2017)

24. S. Islam, M.H. Alfaruqi, J.J. Song, S.J. Kim, D.T. Pham, J.G. Jo, S.H. Kim, V. Mathew, J.P. Baboo, Z. Xiu, J. Kim "Carbon-coated manganese dioxide nanoparticles and their enhanced electrochemical properties for zinc-ion battery applications" J. Energy Chem., 26, 815-819 (2017)

25. C. Yuan, Y. Zhang, Y. Pan, X. Liu, G. Wang, D. Cao, "Investigation of the intercalation of polyvalent cations $\left(\mathrm{Mg}^{2+}, \mathrm{Zn}^{2+}\right)$ into $\lambda-\mathrm{MnO}_{2}$ for rechargeable aqueous battery" Electrochim. Acta, 116, 404-412 (2014)

26. N. Zhang, F. Cheng, Y. Liu, Q. Zhao, K. Lei, C. Chen, X. Liu, J. Chen, "Cation-deficient spinel $\mathrm{ZnMn}_{2} \mathrm{O}_{4}$ cathode in $\mathrm{Zn}\left(\mathrm{CF}_{3} \mathrm{SO}_{3}\right)_{2}$ electrolyte for rechargeable aqueous $\mathrm{Zn}$-ion battery" J. Am. Chem. Soc., 138, 12894-12901 (2016)

27. W. Sun, F. Wang, S. Hou, C. Yang, X. Fan, Z. Ma, T. Cao, F. Han, R. Hu, M. Zhu, C. Wang, " $\mathrm{Zn} / \mathrm{MnO}_{2}$ battery chemistry with $\mathrm{H}^{+}$and $\mathrm{Zn}^{2+}$ co-insertion" $J$. Am. Chem. Soc., 13, 9775-9778 (2017)

28. B. Wu, G. Zhang, M. Yan, T. Xiong, P. He, L. He, X. $\mathrm{Xu}$, L. Mai, "Graphene scroll-coated $\alpha-\mathrm{MnO}_{2}$ nanowires as high-performance cathode materials for aqueous Zn-ion battery" Small, 14(13), 1703850 (2018)

29. M.H. Alfaruqi, S. Islam, V. Mathew, J.J. Song, S.J. Kim, D.T. Pham, J.J. Jo, S.H. Kim, J.P. Baboo, Z. Xiu, J. Kim, "Ambient redox synthesis of vanadiumdoped manganese dioxide nanoparticles and their enhanced zinc storage properties" Appl. Surf. Sci., 404, 435-442 (2017)

30. J.H. Lee, J.B. Ju, W.I. Cho, B.W. Cho, S.H. Oh, "Todorokite-type $\mathrm{MnO}_{2}$ as a zinc-ion intercalating material". Electrochim. Acta, 112, 138-143 (2013)

31. B. Jiang, C. Xu, C. Wu, L. Dong, J. Li, F. Kang, "Manganese Sesquioxide as cathode material for multivalent zinc ion battery with high capacity and long cycle life" Electrochim. Acta, 229, 422-428 (2017)

32. J. Hao, J. Mou, J. Zhang, L. Dong, W. Liu, C. Xu, F. Kang, "Electrochemically induced spinel-layered phase transition of $\mathrm{Mn}_{3} \mathrm{O}_{4}$ in high performance neutral aqueous rechargeable zinc battery" Electrochim. Acta, 259, 170-178 (2018)

33. H. Li, C. Han, Y. Huang, Y. Huang, M. Zhu, Z. Pei,
Q. Xue, Z. Wang, Z. Liu, Z. Tang, Y. Wang, F. Kang, B. Li, C. Zhi, "An extremely safe and wearable solidstate zinc ion battery based on a hierarchical structured polymer electrolyte" Energy Environ. Sci., 11(4), 941-951 (2018)

34. Y. Zeng, Y. Zhang, Y. Meng, M. Yu, J. Yi, Y. Wu, X. $\mathrm{Lu}, \mathrm{Y}$. Tong, "Achieving ultrahigh energy density and long durability in a flexible rechargeable quasi-solidstate $\mathrm{Zn}-\mathrm{MnO}_{2}$ battery" Adv. Mater., 29, 1700274 (2017)

35. D. Kundu, D. Adams, V. Duffort, S.H. Vajargah, L.F. Nazar, "A high-capacity and long-life aqueous rechargeable zinc battery using a metal oxide intercalation cathode" Nat. Energy, 1, 16119 (2016)

36. P. He, G. Zhang, X. Liao, M. Yan, X. Xu, Q. An, J. Liu, L. Mai, "Sodium ion stabilized vanadium oxide nanowire cathode for high-performance zinc-ion batteries" Adv. Energy Mater., 8(10), 1702463 (2018)

37. C. Xia, J. Guo, P. Li, X. Zhang, H.N. Alshareef, "Highly stable aqueous zinc-ion storage using layered calcium vanadium oxide bronze cathode" Angew. Chem. Int. Ed., 57, $1-7$ (2018)

38. M. Yan, P. He, Y. Chen, S. Wang, Q. Wei, K. Zhao, X. Xu, Q. An, Y. Shuang, Y. Shao, K.T. Mueller, L. Mai, J. Liu, J. Yang, "Water-lubricated intercalation in $\mathrm{V}_{2} \mathrm{O}_{5} \cdot \mathrm{nH}_{2} \mathrm{O}$ for high-capacity and high-rate aqueous rechargeable zinc batteries" $A d v$. Mater., 30, 1703725 (2018)

39. M.H. Alfarugi, V. Mathew, J.J. Song, S.J. Kim, S. Islam, D.T. Pham, J.G. Jo, S.H. Kim, J.P. Baboo, Z. Xiu, K.S. Lee, Y.K. Sun, J. Kim "Electrochemical zinc intercalation in lithium vanadium oxide: A highcapacity zinc-ion battery cathode" Chem. Mater., 29, 1684-1694 (2017)

40. P. He, Y. Quan, X. Xu, M. Yan, W. Yang, Q. An, L. He, L. Mai, "High-performance aqueous zinc-ion battery based on layered $\mathrm{H}_{2} \mathrm{~V}_{3} \mathrm{O}_{8}$ nanowire cathode". Small, 13, 1702551 (2017)

41. P. Hu, T. Zhu, X. Wang, X. Wei, M. Yan, J. Li, W. Luo, W. Yang, W. Zhang, L. Zhou, Z. Zhou, L. Mai, "Highly durable $\mathrm{Na}_{2} \mathrm{~V}_{6} \mathrm{O}_{16} \cdot 1.63 \mathrm{H}_{2} \mathrm{O}$ nanowire cathode for aqueous zinc-ion battery" Nano Lett., 18, 1758 -1763 (2018)

42. D. Kundu, S.H. Vajargah, L. Wan, B. Adams, D. Prendergast, L.F. Nazar, "Aqueous vs. non-aqueous $\mathrm{Zn}$-ion batteries: consequences of the desolvation penalty at the interface" Energy Environ. Sci., 11(4), 881 (2018) 


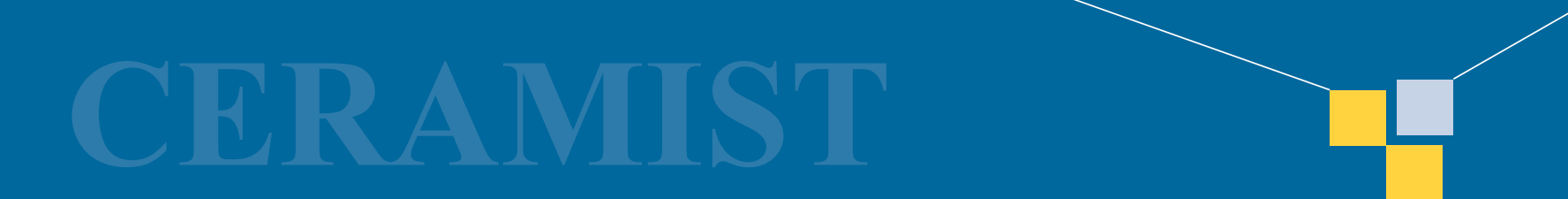

43. B. Sambandam, V. Soundharrajan, S.J. Kim, M.H. Alfaruqi, J.G. Jo, S.H. Kim, V. Mathew, Y.K. Sun, J. Kim, "Aqueous rechargeable $\mathrm{Zn}$-ion batteries: An imperishable and high-energy $\mathrm{Zn}_{2} \mathrm{~V}_{2} \mathrm{O}_{7}$ nanowire cathode through intercalation regulation" $J$. Mater. Chem. A, 5, 3850-3856 (2018)

44. C. Xia, J. Guo, Y. Lei, "Rechargeable aqueous zincion battery based on porous framework zinc pyro vanadate intercalation cathode" $A d v$. Mater., 30, 1705580 (2018)

45. P. He, M. Yan, G. Zhang, R. Sun, L. Chen, Q. An, L. Mai, "Layered $\mathrm{VS}_{2}$ nanosheet-based aqueous $\mathrm{Zn}$ ion battery cathode" Adv. Energy Mater., 7, 1601920 (2017)

46. G. Li, Z. Yang, Y. Jiang, C. Jin, W. Huang, X. Ding, Y. Huang, "Towards polyvalent ion batteries: A zincion battery based on NASICON structured $\mathrm{Na}_{3} \mathrm{~V}_{2}\left(\mathrm{PO}_{4}\right)_{3}$, Nano Energy, 25, 211-217 (2016)

47. L. Zhang, L. Chen, X. Zhou, Z. Liu, "Towards highvoltage aqueous metal-ion batteries beyond $1.5 \mathrm{~V}$ : The zinc/zinc hexacyanoferrate system" $A d v$. Energy. Mater., 5, 1400930 (2015)

48. L. Zhang, L. Chen, X. Zhou, Z. Liu "Morphologydependent electrochemical performance of zinc hexacyanoferrate cathode for zinc-ion battery" Sci. Rep., 5, 18263 (2015)

49. R. Trocoli, F.L. Mantia, "An aqueous zinc-ion battery based on copper hexacyanoferrate" ChemSusChem, 8, 481-485 (2015)

50. Z. Jia, B. Wang, Y. Wang, "Copper hexacyanoferrate with a well-defined open framework as a positive electrode for aqueous zinc ion batteries" Mater. Chem. Phys., 149-150, 601-606 (2015)

51. G. Kasiri, R. Trocoli, A.B. Hashemi, F.L. Mantia, "An electrochemical investigation of the aging of copper hexacyanoferrate during the operation in zinc-ion

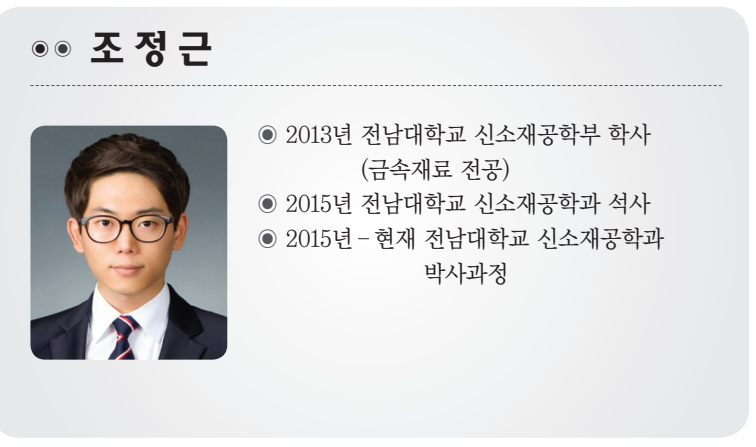

batteries" Electrochim. Acta, 222, 74-83 (2016)

52. A. Khor, P. Leung, M. R. Mohamed, C. Flox, Q. Xu, L. An, R.G.A. Wills, J. R. Morante, A. A. Shah, "Review of zinc-based hybrid flow batteries: From fundamentals to application" Mater. Today Energy, 8, 80-108 (2018)

53. Y. Li, H. Dai, "Recent advances in Zinc-air batteries" Chem. Soc. Rev., 43(15), 5257-5275

54. S.H. Lee, C.W. Yi, K. Kim, "Characteristics and Electrochemical performance of the $\mathrm{TiO}_{2}-$ coated $\mathrm{ZnO}$ anode for Ni-Zn secondary batteries" J. Phys. Chem. C, 115(5), 2572-2577 (2011)

55. J. Huang, Z. Guo, Y. Ma, D. Bin, Y. Wang, Y. Xia, "Recent Progress of Rechargeable Batteries Using Mild Aqueous Electrolytes" Small Methods, 1800272 (2018)

56. J. F. Parker, C. N. Chervin, I. R. Pala, M. Machler, M. F. Burz, J. W. Long, D. R. Rolison, "Rechargeable nickel-3D zinc batteries: An energy-dense, safer alternative to lithium-ion" Science, 356, 415-418 (2017)

57. H. Li, C. Xu, C. Han, Y. Chen, C. Wei, B. Li, F. Kang, "Enhancement on Cycle Performance of Zn Anodes by Activated Carbon Modification for Neutral Rechargeable Zinc Ion Batteries“ J. Electrochem. Soc., 162, A1439 (2015)

58. M.S. Chae, J.W. Heo, S.C. Lim, S.T. Hong, "Electrochemical zinc-ion intercalation properties and crystal structures of $\mathrm{ZnMo}_{6} \mathrm{~S}_{8}$ and $\mathrm{Zn}_{2} \mathrm{Mo}_{6} \mathrm{~S}_{8}$ chevrel phases in aqueous electrolytes" Inorg. Chem., 55, 3294-3301(2016)

59. W. Kaveevivitchai, A. Manthiram, "High-capacity zinc-ion storage in an open-tunnel oxide for aqueous and non-aqueous Zn-ion batteries" J. Mater. Chem. A, 4, 18737-18741 (2016)

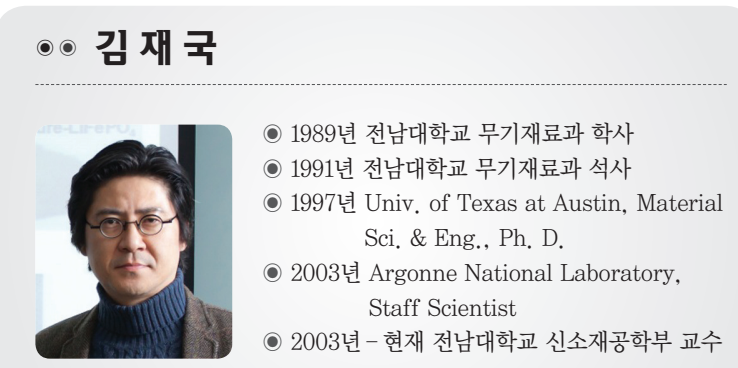

